\title{
Time-dependent shifts in populations and activity of bacterial and archaeal ammonia oxidizers in response to liming in acidic soils
}

\author{
Miao-Miao Zhang a, Ricardo J.E. Alves ${ }^{\text {b }}$, Dan-Dan Zhang a, c, Li-Li Han a, Ji-Zheng He a , \\ Li-Mei Zhang a, * \\ a State Key Laboratory of Urban and Regional Ecology, Research Center for Eco-Environmental Sciences, Chinese Academy of Sciences, Beijing 100085, China \\ ${ }^{\mathrm{b}}$ Department of Ecogenomics and Systems Biology, Division of Archaea Biology and Ecogenomics, Faculty of Life Sciences, University of Vienna, \\ Althanstrasse 14 UZA I, A-1090 Vienna, Austria \\ ${ }^{\mathrm{c}}$ University of Chinese Academy of Sciences, Beijing 100049, China
}

\section{A R T I C L E I N F O}

\section{Article history:}

Received 17 November 2016

Received in revised form

30 April 2017

Accepted 1 May 2017

Available online 10 May 2017

\section{Keywords:}

Ammonia-oxidizing bacteria (AOB)

Ammonia-oxidizing archaea $(\mathrm{AOA})$

Nitrification

$\mathrm{N}$ fertilizers

Liming

Acidic soils

\begin{abstract}
A B S T R A C T
During the past decades, extensive nitrogen fertilization and acid deposition have greatly contributed to soil acidification in agroecosystems. Liming, the addition of calcium- and magnesium-rich material to soil, is an effective management strategy used to improve fertility and productivity of agricultural soils degraded by acidification. Nitrification plays a central role in nitrogen $(\mathrm{N})$ availability in agroecosystems and contributes to soil acidification. However, little is known regarding the effects of liming on this process and microbial populations that drive it. Here, we investigated population dynamics and activity of ammonia oxidizers in response to a 2-year liming field trial in acidic soils received long-term fertilization with chemical $\mathrm{N}$ fertilizers and short-term lime amendment in microcosm incubations. Our results showed that activity, abundance and population structure of both ammonia-oxidizing archaea (AOA) and bacteria (AOB) were sensitive to liming in fertilized acidic soils. AOB abundance and potential nitrification rates increased in field plots subjected to liming, whereas the opposite was observed for AOA. In microcosm incubations, AOA abundance increased progressively over 60 days, namely under low $\mathrm{CaO}$ levels, whereas $\mathrm{AOB}$ abundance was greatly stimulated only during the first week under high $\mathrm{CaO}$ levels. ${ }^{13} \mathrm{CO}_{2}$-SIP-DNA experiments further supported that AOA were the most active ammonia oxidizers in fertilized field soils. However, in $\mathrm{N}$-fertilized soils freshly amended with $\mathrm{CaO}$, only autotrophic growth of $A O B$ was observed after seven days, but not after 30 days when growth of AOA was observed. Taken together, our results indicated that both $A O A$ and $A O B$ play a role in nitrification following liming in fertilized acidic soils, likely through selection of better adapted clades of organisms. Although AOA were likely the main drivers of nitrification in these soils in the long-term, liming stimulated AOB activity in the short-term.
\end{abstract}

() 2017 Elsevier Ltd. All rights reserved.

\section{Introduction}

Acidic soils, defined as having $\mathrm{pH}$ below 5.5, occupy a vast extension of the terrestrial surface, comprising about $30 \%$ of the world's total ice-free areas (Uexküll and Mutert, 1995). During the past decades, high levels of nitrogen fertilizer application and acid deposition have led to soil acidification and consequent lower crop yields and disturbances of the N cycle (Guo et al., 2010; Wallace, 1994). Liming, the application of calcium- and magnesium-rich

\footnotetext{
* Corresponding author.

E-mail address: zhanglm@rcees.ac.cn (L.-M. Zhang).
}

material to soils, such as limestone (Álvarez et al., 2009), calcium carbonate (Fornara et al., 2011) and calcium oxide (CaO) (Kerley, 2000; Zaniewicz-Bajkowska et al., 2007), is commonly employed to improve quality and productivity of acidic soils (Caires et al., 2008; Lollato et al., 2013). It has been reported that liming can decrease water repellence in sandy soils and increase microbial biomass and respiration associated with acid-intolerant soil microorganisms (Avrahami and Bohannan, 2007; Park et al., 2006; Xiao et al., 2014). The influence of lime amendment on $\mathrm{N}$ turnover in acidic soils have also been reported, including $\mathrm{N}$ mineralization, $\mathrm{N}$ fixation, nitrification and $\mathrm{N}_{2} \mathrm{O}$ emissions (Abell et al., 2012; Avrahami and Bohannan, 2007; Barton et al., 2013; Shanmugam et al., 2014). 
Nitrification, the conversion of ammonia to nitrate via nitrite, is a central process in global nitrogen $(\mathrm{N})$ cycling that greatly contributes to lower $\mathrm{N}$ fertilizer efficiency, and groundwater and atmospheric pollution through nitrate leaching and emission of reactive $\mathrm{N}$ species, respectively (Farmaha, 2014; Wrage et al., 2001). Furthermore, nitrification is also directly and indirectly involved in soil acidification through generation of nitrous acid and proton release, and loss of basic cations through nitrate leaching (Bernhard, 1986; Bolan and Hedley, 2005; Helyar and Porter, 1989). Ammonia oxidation, the first and rate-limiting step of nitrification, was thought to be catalyzed primarily by autotrophic ammoniaoxidizing bacteria (AOB) belonging to $\beta$ - or $\gamma$-proteobacteria, with very limited contributions from heterotrophic bacteria and fungi in some soils (De Boer and Kowalchuk, 2001; Prosser, 1990). However, metagenomic and cultivation studies revealed that ammonia-oxidizing archaea (AOA) are also able to grow chemolithoautotrophically by aerobically oxidizing ammonia to nitrite (Konneke et al., 2005; Leininger et al., 2006; Treusch et al., 2005; Venter et al., 2004). AOA and AOB generally occupy distinct environmental niches, with AOA being numerically and functionally dominant in most acidic soils (Prosser and Nicol, 2012). Nitrification activity in some acidic soils has been positively correlated with AOA abundance (Yao et al., 2011; Zhang et al., 2012), and changes in nitrification activity have also been associated to changes in AOA community composition (Gubry-Rangin et al., 2010; Lu et al., 2012; Zhang et al., 2012). Further evidence was provided by ${ }^{13} \mathrm{CO}_{2}$-DNASIP experiments showing autotrophic growth of AOA, but not of AOB, in nitrifying acidic tea orchard soil (Zhang et al., 2012). By contrast, AOB have been shown to generally dominate ammonia oxidizer populations and nitrification activity in neutral and alkaline soils, as shown by ${ }^{13} \mathrm{CO}_{2}$-DNA-SIP experiments (Jia and Conrad, 2009; Xia et al., 2011), as well as in soils subjected to high nitrogen inputs, based on inhibition experiments (Di et al., 2009). Nevertheless, AOB are often present in acidic soils and in some cases their abundance is comparable, or higher, than that of AOA (Andert et al., 2011; Long et al., 2012; Pereira et al., 2012). Moreover, potential nitrification rates in some acidic soils have been shown to be positively correlated with abundance and community structure dynamics of AOB (Fan et al., 2011; Gleeson et al., 2010; Ying et al., 2010). DNA-SIP experiments also indicated that recovery of nitrification and subsequent zinc tolerance after long-term zinc exposure in an acidic soil was initially driven by AOB rather than AOA (Ruyters et al., 2013). Such evidence indicates that, despite AOA dominance, acidic soils also harbour active and dynamic AOB populations, although their role in nitrification and response to disturbances in such soils remain unclear. In fact, increases in AOB abundance have been observed following lime application in acidic soils (Barton et al., 2013; Che et al., 2015; Rotthauwe et al., 1997), although long-term and short-term effects of lime application on ammonia oxidizer community structure and nitrification activity have not been evaluated.

In our previous work with upland red soils ( $\mathrm{pH} 3.7-6.0)$ from the Qiyang Red Soil Experimental Station in Hunan Province, China, which was continuously fertilized over a 16-year period, we found that inorganic $\mathrm{N}$ fertilization significantly reduced soil $\mathrm{pH}$ and $\mathrm{AOB}$ abundance, and markedly changed AOA community composition (He et al., 2007). In 2010, field plots under inorganic $\mathrm{N}$ fertilization were subjected to liming with $\sim 1000 \mathrm{ppm} \mathrm{CaO}$, as an attempt to alleviate soil acidification. The current study aims to assess the long- and short-term responses of AOA and AOB populations to liming in acidic soils under continuous fertilization and their effect on nitrification. Additionally, we aim to further elucidate the particular role of AOB in acidic soils, as it might be currently underestimated. We addressed these questions by analyzing $\mathrm{NH}_{4}^{+}$ and $\mathrm{NO}_{3}^{-}$pool dynamics, potential nitrification rates (PNRs) and ammonia oxidizer abundance and community structure, through quantitative PCR (qPCR) and amoA gene sequencing, respectively, in soils subject to different fertilizers after a 2-year field liming trial and 2-month laboratory soil incubations with and without lime amendment. Furthermore, ${ }^{13} \mathrm{CO}_{2}$-DNA-SIP experiments were performed following similar laboratory soil incubations to determine the active ammonia populations after short-term lime amendment.

\section{Materials and methods}

\subsection{Soil collection and sample characterization}

Soils were collected from a long-term fertilization trial at the Qiyang Red Soil Experimental Station $\left(26^{\circ} 45^{\prime} \mathrm{N}, 111^{\circ} 52^{\prime} \mathrm{E}\right)$, Hunan Province, China. The site has a subtropical monsoon climate with an annual rainfall of $1300 \mathrm{~mm}$ and annual average temperature of $18{ }^{\circ} \mathrm{C}$, and the soil developed from quaternary red clay earth and classified as agri-udic ferrosols. The long-term fertilization trial was established in 1990 with a wheat-maize rotation system, including three replicate plots under eight treatments of fallow, control without fertilizers (Control) and different combinations of nitrogen $(\mathrm{N})$, potassium $(\mathrm{K})$, phosphate $(\mathrm{P})$ and organic manure fertilizers (He et al., 2007). Due to high soil acidification in plots subject to annual inputs of N, NK, NP and NPK fertilizers since 1990, at rates of $300 \mathrm{~kg} \mathrm{ha}^{-1} \mathrm{~N}, 120 \mathrm{~kg} \mathrm{ha}^{-1} \mathrm{P}_{2} \mathrm{O}_{5}, 120 \mathrm{~kg} \mathrm{ha}^{-1} \mathrm{~K}_{2} \mathrm{O}$, in 2010 , half of the plots were amended with $2250 \mathrm{~kg} \mathrm{ha}^{-1} \mathrm{CaO}$ (equivalent to $1000 \mathrm{ppm}$ ) to alleviate soil acidification. $\mathrm{CaO}$ powder was broadcasted in fallow season only once in 2010 and mixed with soil by subsequent manual plough. For the current study, we selected soils under chemical $\mathrm{N}$ fertilizer treatments (N, NK, NP, NPK), the corresponding liming treatments $(\mathrm{N}+\mathrm{CaO}, \mathrm{NK}+\mathrm{CaO}, \mathrm{NP}+\mathrm{CaO}$ and $\mathrm{NPK}+\mathrm{CaO}$ ) and untreated Control soil. Soil samples were collected from a depth of $0-20 \mathrm{~cm}$ in July 2012. Five soil cores were collected from each plot and homogenized into one composite sample. All samples were passed through a $2.0 \mathrm{~mm}$ sieve and stored at $4{ }^{\circ} \mathrm{C}$ for soil physico-chemical analyses and microcosm incubations, whereas subsamples for molecular analyses were immediately stored at $-80^{\circ} \mathrm{C}$.

Soil $\mathrm{pH}_{(\mathrm{KCl})}$ was determined using a Delta $320 \mathrm{pH}$-meter (Mettler-Toledo Instruments Co., Shanghai, China) after suspended with $1 \mathrm{M} \mathrm{KCl}$. Soil ammonium and nitrate pools were extracted with $1 \mathrm{M}$ $\mathrm{KCl}$ and measured with a Continuous Flow Analyzer (SAN++, Skalar, Breda, Holland). Potential nitrification rates (PNR) were determined using the chlorate inhibition method as described by Kurola and colleagues (Kurola et al., 2005). Briefly, for each assay, $5.0 \mathrm{~g}$ of fresh soil was suspended in $20 \mathrm{~mL}$ phosphate buffer solution (PBS) ( $\mathrm{g} \mathrm{L}^{-1}$ : $\mathrm{NaCl} 8.0, \mathrm{KCl} 0.2, \mathrm{Na}_{2} \mathrm{HPO}_{4} 0.2, \mathrm{NaH}_{2} \mathrm{PO}_{4} 0.2, \mathrm{pH}$ 7.4) and $1 \mathrm{mM}\left(\mathrm{NH}_{4}\right)_{2} \mathrm{SO}_{4}$ as substrate. Potassium chlorate was added to a final concentration of $10 \mathrm{mM}$ to inhibit nitrite oxidation. The soil suspension was incubated in the dark for $24 \mathrm{~h}$ at $25^{\circ} \mathrm{C}$, while shaking at $180 \mathrm{rpm}$. Soil nitrite was extracted with $5 \mathrm{~mL} 2 \mathrm{M}$ $\mathrm{KCl}$ and measured at $540 \mathrm{~nm}$ based on the Griess method using sulphonamide and naphthylethelene diamide. Soil organic carbon (SOC) was extracted with $70{ }^{\circ} \mathrm{C}$ hot water and measured with a Total Organic Carbon Analyzer (Fusion/Torch, Tekmar Dohrmann, USA), as described by Wang and Wang, 2011.

\subsection{Soil microcosm incubations}

Microcosm experiment 1 ( $\mathrm{CaO}$ amendment): Short-term soil incubations were performed with soil from the long-term field $\mathrm{N}$ treatment amended prior to incubation with 500, 1000 and $2000 \mathrm{ppm} \mathrm{CaO}$ powder, in addition to the control without $\mathrm{CaO}$, and designated $\mathrm{N}+500, \mathrm{~N}+1000$ and $\mathrm{N}+2000$ and $\mathrm{N}$ (control), respectively. Incubations were performed in $120 \mathrm{ml}$ serum bottles 
containing $10 \mathrm{~g}$ fresh samples and covered with aluminium foil. Briefly, CaO powder was separately added into each bottle with a final concentration of 500, 1000 and 2000 ppm, and thoroughly mixed with the soils prior to adjust soil moisture to $60 \%$ field moisture capacity. Microcosms were incubated at $28^{\circ} \mathrm{C}$ in the dark. The water content of soils was maintained by resupplying the lost water every 3 days throughout the incubation. Three replicates from each treatment were destructively sampled at $0,7,15,30$ and 60 days, immediately subsampled for ammonium and nitrate extractions and the remaining samples were frozen at $-80{ }^{\circ} \mathrm{C}$ for molecular analysis.

Microcosm experiment 2 (Stable Isotope Probing incubation): Short-term soil incubations for SIP analysis were performed with soils from the long-term field $\mathrm{N}$ and $\mathrm{N}+\mathrm{CaO}$ treatments. An additional incubation was performed with soil from the field $\mathrm{N}$ treatment amended with $1000 \mathrm{ppm} \mathrm{CaO}$ prior to incubation $(\mathrm{N}+1000)$. Microcosms were performed in $120 \mathrm{ml}$ serum bottles containing $10 \mathrm{~g}$ of the fresh samples and sealed with rubber stoppers and aluminium caps. The headspace of the bottles was adjusted to $5 \%$ (v/v) of either ${ }^{12} \mathrm{C}-\mathrm{CO}_{2}$ or ${ }^{13} \mathrm{C}_{-} \mathrm{CO}_{2}$ (99 atom\%, SigmaAldrich Co., St Louis, MO, USA) by injection through the rubber septum. Air in the headspace was renewed every 3 days by opening the bottles and then re-establishing the $\mathrm{CO}_{2}$ concentration. $\mathrm{Mi}$ crocosms were incubated at $28{ }^{\circ} \mathrm{C}$ in the dark, and three replicates from each treatment were destructively sampled at 0,7 and 30 days, as described above.

\subsection{DNA extraction and quantitative PCR of amoA genes}

Soil DNA was extracted from $0.25 \mathrm{~g}$ samples with the MoBio PowerSoil ${ }^{\mathrm{TM}}$ DNA Kit (MO BIO laboratories, CA, US), according to the manufacturers' protocol. Extracted DNA was verified on 1\% agarose gel and concentrations were determined photometrically using a Nanodrop ND-1000 UV-Vis spectrophotometer (NanoDrop Technologies, Wilmington, DE, USA).

Archaeal and bacterial $a m o A$ genes were quantified by quantitative PCR (qPCR) using the primers Arch-amoAF/Arch-amoAR (Francis et al., 2005) and amoA-1F/amoA-2R (Rotthauwe et al., 1997), respectively. PCR reactions were performed in $25 \mu \mathrm{l} \mathrm{vol-}$ umes containing $12.5 \mu$ l SYBR ${ }^{\mathbb{R}}$ Premix Ex Taq ${ }^{\mathrm{TM}}$ (TaKaRa Biotechnology, Otsu, Shiga, Japan), $200 \mathrm{nM}$ of each primer and $2 \mu$ l of 5-fold diluted template DNA (1-10 ng). qPCR was performed in an iCycler iQ 5 thermocycler (Bio-Rad Laboratories, Hercules, CA, USA) using the following thermal conditions: $2 \mathrm{~min}$ at $95^{\circ} \mathrm{C}, 35$ cycles of $10 \mathrm{~s}$ at $95{ }^{\circ} \mathrm{C}, 30 \mathrm{~s}$ at $53{ }^{\circ} \mathrm{C}$ for $\mathrm{AOA}$ and $55^{\circ} \mathrm{C}$ for $\mathrm{AOB}$, and $1 \mathrm{~min}$ at $72{ }^{\circ} \mathrm{C}$ followed by a plate reading step at $81^{\circ} \mathrm{C}$. Standard curves for the qPCR assays were generated as described previously (He et al., 2007), and quantification efficiencies varied between $80 \%-120 \%$ with $\mathrm{R}^{2}$ values $>0.99$. All $\mathrm{qPCR}$ reactions were performed in triplicate.

\subsection{Cloning, sequencing and phylogenetic analysis}

A preliminary screening of $\mathrm{AOA}$ and $\mathrm{AOB}$ community compositions with Denaturing Gradient Gel Electrophoresis (DGGE) of amoA genes indicated that ammonia oxidizer population structure was similar among $\mathrm{N}$ fertilizer treatments (N, NK, NP, NPK) and among liming treatments $(\mathrm{N}+\mathrm{CaO}, \mathrm{NK}+\mathrm{CaO}, \mathrm{NP}+\mathrm{CaO}$, $\mathrm{NPK}+\mathrm{CaO}$ ) (data not shown), but differed mostly between nonliming and liming treatments. Therefore, five field samples, Control, $\mathrm{N}, \mathrm{NPK}, \mathrm{N}+\mathrm{CaO}$ and NPK $+\mathrm{CaO}$, and samples collected at days 0,7 and 30 from the $\mathrm{N}, \mathrm{N}+1000$ and $\mathrm{N}+\mathrm{CaO}$ treatments of the ${ }^{13} \mathrm{CO}_{2}$-SIP-DNA incubations (experiment 2) were selected for $a m o A$ gene cloning and sequencing. Archaeal and bacterial $a m o A$ genes were amplified with primers CrenamoA-23f/CrenamoA-616r
(Tourna et al., 2008) and amoA-1F/amoA-2R (Rotthauwe et al., 1997). PCR was performed in a $25 \mu l$ reaction volume containing $12.5 \mu$ Premix Ex Taq ${ }^{\mathrm{TM}}$ (TaKaRa Biotechnology, Otsu, Shiga, Japan), $200 \mathrm{nM}$ primer for AOA or $160 \mathrm{nM}$ primer for AOB and $2 \mu \mathrm{l}$ DNA template, using the following thermal condition: 5 min $95^{\circ} \mathrm{C}, 10$ cycles of $30 \mathrm{~s}$ at $94{ }^{\circ} \mathrm{C}, 30 \mathrm{~s}$ at $55^{\circ} \mathrm{C}$, and $1 \mathrm{~min}$ at $72{ }^{\circ} \mathrm{C}$, then 25 cycles of $30 \mathrm{~s}$ at $92^{\circ} \mathrm{C}, 30 \mathrm{~s}$ at $55^{\circ} \mathrm{C}$, and $1 \mathrm{~min}$ at $72{ }^{\circ} \mathrm{C}$ followed by $72{ }^{\circ} \mathrm{C}$ at $10 \mathrm{~min}$. All PCR reactions were performed in triplicate.

A total of 1047 archaeal (20-48 clones per sample) and 862 bacterial (20-34 clones per sample) amoA gene sequences were obtained from soil samples of five field plots under different treatments and from three time-points of SIP microcosm incubations under three different treatments. Triplicate clone libraries were performed from all samples/time-points, except from day 0 of the incubation experiment (one or two replicates per day 0 sample, for $\mathrm{AOA}$ and $\mathrm{AOB}$, respectively). No bacterial amoA genes were obtained from day 30 samples of the incubation, due to unsuccessful PCR amplification. Individual archaeal and bacterial amoA gene datasets were aligned with MAFFT (FFT-NS-i method) (Katoh and Standley, 2013), primers were trimmed and sequences containing stop codons or indels causing frame-shifts were excluded. Datasets were filtered for chimeras and clustered into operational taxonomic units (OTUs) at $97 \%$ sequence identity with UPARSE (Edgar, 2013). The quality-checked datasets comprised 1013 sequences with 592 bp clustered into 33 OTUs for AOA, and 818 sequences with 447 bp clustered into 44 OTUs for AOB. Selection of the best-fit model of DNA evolution, tree inference and calculation of Ultrafast Bootstrap (UFBoot) (Minh et al., 2013) and SH-aLRT (Guindon et al., 2010) support values (1000 replicates each) were performed by maximum-likelihood with IQ-TREE (Nguyen et al., 2015). Phylogenetic tree calculations were based on the TVM and K3Pu models of DNA evolution for archaeal and bacterial amoA gene sequences, respectively, both with a FreeRate model of substitution rate heterogeneity with four categories $(+R 4)$ (Soubrier et al., 2012). Nucleotide sequences obtained in this study were deposited in GenBank under accession numbers KX666100 to KX666917 and KX666918 to KX667930 for bacterial and archaeal amoA genes sequences, respectively.

\subsection{SIP fractionation}

DNA extracted from ${ }^{12} \mathrm{C}$ - and ${ }^{13} \mathrm{C}-\mathrm{CO}_{2}$ incubations was subjected to isopycnic density gradient centrifugation, as described by Zhang et al. (2012). Briefly, a CsCl solution with a buoyant density of $1.696 \mathrm{~g} \mathrm{ml}^{-1}$ was prepared in TE buffer ( $\mathrm{pH}$ 8.0) and adjusted to a refractive index of 1.3999 with an ATAGO-R-5000 hand-held refractometer (UNI-IT, Tokyo, Japan). DNA $(\sim 2 \mu \mathrm{g})$ was added to the $\mathrm{CsCl}$ solution in $4.9 \mathrm{ml}$ OptiSeal polyallomer tubes (Beckman Coulter, Palo Alto, CA, USA), and then subjected to centrifuge at $227,962 \mathrm{~g}(56,200 \mathrm{rpm})$ for $24 \mathrm{~h}$ at $20^{\circ} \mathrm{C}$ in a VTi 90 vertical rotor (Beckman Coulter). Centrifuged $\mathrm{CsCl}$ gradients were fractionated into 24 equal volumes $(\sim 200 \mu \mathrm{l})$ by injecting sterile water on the top to replace $\mathrm{CsCl}$ gradient solution using a fraction recovery system (Beckman Coulter). Buoyant densities of each fraction were measured by determining their refractive index in $20 \mu$ laliquots. Nucleic acids were precipitated from $\mathrm{CsCl}$ overnight with two volumes of PEG 6000 in $1.6 \mathrm{M} \mathrm{NaCl}$, washed with $70 \%$ ethanol and then eluted in $30 \mu \mathrm{l}$ of sterile water.

\subsection{Statistical analysis}

Analysis of variance in soil $\mathrm{pH}, \mathrm{SOC}, \mathrm{NH}_{4}^{+}$and $\mathrm{NO}_{3}^{-}$concentrations, PNR and log-transformed amoA gene copy numbers were performed with one-way ANOVA followed by S-N-K $(n \geq 3)$ and paired T $(n=2)$ tests using SPSS version 19.0 (IBM Co., Armonk, NY, 
USA), respectively. $P$ values below 0.05 were considered statistically significant.

\section{Results}

\subsection{Field soil properties, potential nitrification rates and ammonia oxidizer populations}

Significant differences $(P<0.05)$ in soil pH (Table 1$)$ were observed between mineral $\mathrm{N}$ fertilizer treatments (N, NK, NP, NPK) and the corresponding liming treatments $(\mathrm{N}+\mathrm{CaO}, \mathrm{NK}+\mathrm{CaO}$, $\mathrm{NP}+\mathrm{CaO}$ and $\mathrm{NPK}+\mathrm{CaO})$. Soil $\mathrm{pH}_{(\mathrm{KCl})}$ in plots treated with mineral $\mathrm{N}$ fertilizers (N, NK, NP and NPK) was significantly lower than in untreated control plots, ranging between 3.35 and 3.47, whereas liming changed soil acidity, resulting in significantly higher soil $\mathrm{pH}$ in all limed plots (4.10-4.46; $P<0.05$ ) (Table 1$)$. Liming also induced significantly higher PNRs, which ranged between 0.02 and $0.14 \mathrm{mg} \mathrm{NO}_{2}^{-}-\mathrm{N} \mathrm{kg}^{-1} \mathrm{~h}^{-1}$ in the $\mathrm{N}$ fertilized soils and between 0.22 and $0.34 \mathrm{mg} \mathrm{NO}-\mathrm{N} \mathrm{kg}^{-1} \mathrm{~h}^{-1}$ in the corresponding limed soils $(P<0.05)$ (Table 1$)$. Similar to our previous observations in the same experimental plots 6 years earlier (He et al., 2007), PNRs in unfertilized control soils were significantly higher than in $\mathrm{N}$ fertilized soils and showed a significant positive correlation with soil $\mathrm{pH}(\mathrm{r}=0.78, \mathrm{n}=27, \mathrm{P}<0.01$ ) (Table 1 , Fig. S1). Ammonium concentrations did not differ significantly between treatments, whereas three of the $\mathrm{N}$-fertilized soils (i.e., N, NK, NP) showed significantly higher $\mathrm{NO}_{3}^{-}$concentrations than soils under any other treatment $(P<0.05)$ (Table 1$)$. SOC concentrations in three of the Pfertilized soils (i.e., NP, NPK and NPK $+\mathrm{CaO}$ ) were significantly higher than those in soils under other treatments $(P<0.05)$ (Table 1).

The largest $\mathrm{AOA}$ and $\mathrm{AOB}$ populations were detected in the Control and NPK $+\mathrm{CaO}$ treatment, and the smallest under $\mathrm{N}+\mathrm{CaO}$ and $\mathrm{N}$ treatments, respectively (Table 1 ). AOA abundance were significantly more abundant than $\mathrm{AOB}$ in all treatments without $\mathrm{CaO}(P<0.05)$, with AOA:AOB ratios between 10.9 and 148.7. Paired T-test analysis showed that AOB abundance increased, while AOA decreased significantly $(P<0.05)$ in limed soils $(\mathrm{N}+\mathrm{CaO}, \mathrm{NK}+\mathrm{CaO}$, $\mathrm{NP}+\mathrm{CaO}, \mathrm{NPK}+\mathrm{CaO})$ than in the corresponding treatments without lime amendment (N, NK, NP, NPK) (Table 1), resulting in lower AOA:AOB ratios between 0.83 and 1.94. Soil PNR showed no significant correlation with $\mathrm{AOA}$ nor $\mathrm{AOB}$ abundance but was rather positively correlated with total ammonia oxidizer population size, i.e., the sum of $\mathrm{AOA}$ and $\mathrm{AOB}$ abundances $(\mathrm{r}=0.40, \mathrm{n}=9, P<0.05)$.

Five field treatments (Control, N, N $+\mathrm{CaO}, \mathrm{NPK}$ and $\mathrm{NPK}+\mathrm{CaO}$ ) were selected for in-depth community analysis by amo $A$ gene cloning and sequencing. Archaeal amoA gene sequences were affiliated with nine distinct phylogenetic clades associated with the order Nitrososphaerales, following the classification by Alves et al.
(2013) (clades A, B, C and Nitrososphaera), extended here to accommodate diversity not detected in that study (clades $\mathrm{E}$ and $\mathrm{F}$ ), as well as an additional clade, clade Nitrosotalea, after the genus $\mathrm{Ca}$. Nitrosotalea representing the order $\mathrm{Ca}$. Nitrosotaleales (Kerou et al., 2016) (Fig. 1a and S2). As previously observed by He et al. (2007), long-term application of chemical $\mathrm{N}$ fertilizers greatly affected $\mathrm{AOA}$ community composition in these soils (Fig. 1a). Liming, however, had a pronounced effect on AOA community composition in soils fertilized with only $\mathrm{N}$ but not with NPK. Clade B dominated most AOA populations, comprising $68-79 \%$ of AOA under all treatments, except in soils fertilized only with $\mathrm{N}$ (Fig. 1a). Clade B represents a phylogenetically broad lineage encompassing distinct sub-lineages, which responded differently to soil treatments and therefore were designated here as sub-clades B1 to B4 (Fig. 1a). Nearly all AOA in clade B were affiliated with subclades B1 or B3, with the later dominating in most soils. Clade $\mathrm{C}$ and Nitrosotalea were detected in fertilized soils but not in untreated control soil, with relative abundances ranging from $12 \pm 4 \%$ to $53 \pm 8 \%$ and from $2 \pm 1 \%$ to $15 \pm 4 \%$, respectively (Fig. 1 a). The majority of bacterial amoA gene sequences detected were affiliated with six clades represented by cultivated Nitrosospira strains, mostly corresponding to environmental clades defined by (Zhang et al., 2009) (Fig. 1b and S3). AOB affiliated with the Nitrosomonas genus, related to Nitrosomonas sp. Is79A3, were only detected in untreated control soils. AOB populations were dominated by Nitrosospira sp. Nsp65/L115 clade under N, NPK and NPK + CaO treatments, and by Nitrosospira sp. Nsp2/ Nsp17 clade in the control and $\mathrm{N}+\mathrm{CaO}$-treated soils (Fig. 1b). Both fertilization and liming had a profound effect on the relative abundance of the dominant AOB clades: the relative abundance of Nitrosospira sp. Nsp65/L115 clade was, in average, higher in both non-limed fertilized soils (N: $51 \pm 12 \%$ and NPK: $90 \pm 10 \%$ ) than in the Control $(37 \pm 17 \%)$, whereas the opposite was observed for Nitrosospira sp. Nsp2/Nsp17 clade, which was less abundant under $\mathrm{N}$ treatment $(26 \pm 5 \%)$ than in the Control $(48 \pm 18 \%)$ and not detected under NPK treatment (Fig. 1b). Moreover, the relative abundance of Nitrosospira sp. Nsp2/Nsp17 clade was consistently higher in limed soils ( $\mathrm{N}+\mathrm{CaO}: 84 \pm 3 \%$ and $\mathrm{NPK}+\mathrm{CaO}: 20 \pm 6 \%$ ) than in the corresponding non-limed soils (N: $26 \pm 5 \%$ and NPK: undetected).

\subsection{Microcosm incubation of soils amended with $\mathrm{CaO}$}

In order to assess short-term responses of ammonia oxidizers to liming and associated changes in $\mathrm{pH}$, microcosms with soil subjected to $\mathrm{N}$ treatment were incubated for two months without $\mathrm{CaO}$ addition or with addition of 500, 1000 or 2000 ppm CaO (N, $\mathrm{N}+500, \mathrm{~N}+1000$ and $\mathrm{N}+2000$ treatments, respectively). Liming generally increased soil $\mathrm{pH}$ significantly which remained stable in every treatment throughout the incubation period. The highest $\mathrm{pH}$

Table 1

Soil properties, potential nitrification rates (PNR) and ammonia oxidizer abundances in soils from the 2-year field trials.

\begin{tabular}{|c|c|c|c|c|c|c|c|c|}
\hline Treatment & $\begin{array}{l}\mathrm{H}_{2} \mathrm{O} \\
(\%)\end{array}$ & $\begin{array}{l}\mathrm{pH} \\
(\mathrm{KCl})\end{array}$ & $\begin{array}{l}\mathrm{NH}_{4}^{+}-\mathrm{N} \\
\left(\mathrm{mg} \mathrm{kg}^{-1}\right)\end{array}$ & $\begin{array}{l}\mathrm{NO}_{3}^{-}-\mathrm{N} \\
\left(\mathrm{mg} \mathrm{kg}^{-1}\right)\end{array}$ & $\begin{array}{l}\mathrm{SOC} \\
\left(\mathrm{mg} \mathrm{kg}^{-1}\right)\end{array}$ & $\begin{array}{l}\text { PNR } \\
\left(\mathrm{mg} \mathrm{NO}_{2}^{-}-\mathrm{N} \mathrm{kg}^{-1} \mathrm{~d}^{-1}\right)\end{array}$ & $\begin{array}{l}\text { AOB } \\
\left(\times 10^{7} \text { copies } g^{-1}\right)\end{array}$ & $\begin{array}{l}\text { AOA } \\
\left(\times 10^{8} \text { copies } g^{-1}\right)\end{array}$ \\
\hline $\mathrm{Ctrol}^{\mathrm{a}}$ & $10.64 \pm 0.10^{b}$ & $4.43 \pm 0.09 c$ & $10.88 \pm 0.57 a$ & $0.69 \pm 0.19 a$ & $54.63 \pm 10.79 \mathrm{ab}$ & $10.46 \pm 0.39 h$ & $0.94 \pm 0.14$ & $13.9 \pm 4.68$ \\
\hline $\mathrm{N}$ & $12.29 \pm 0.24$ & $3.35 \pm 0.01 a$ & $19.86 \pm 3.08 a$ & $12.93 \pm 0.34 d$ & $60.46 \pm 4.54 \mathrm{ab}$ & $0.56 \pm 0.10 a$ & $0.41 \pm 0.08$ & $0.85 \pm 0.22$ \\
\hline NK & $13.48 \pm 0.40$ & $3.41 \pm 0.01 a$ & $14.44 \pm 2.01 \mathrm{a}$ & $12.46 \pm 0.56 c d$ & $69.22 \pm 9.32 \mathrm{ab}$ & $2.17 \pm 0.10 c$ & $1.13 \pm 0.44$ & $2.11 \pm 0.53$ \\
\hline NP & $12.92 \pm 0.99$ & $3.42 \pm 0.03 a$ & $13.30 \pm 0.43 a$ & $11.66 \pm 0.49 c$ & $125.84 \pm 12.01 \mathrm{c}$ & $1.42 \pm 0.06 b$ & $5.13 \pm 2.73$ & $5.59 \pm 1.87$ \\
\hline NPK & $13.53 \pm 0.68$ & $3.47 \pm 0.02 \mathrm{a}$ & $6.75 \pm 0.48 a$ & $1.94 \pm 0.40 \mathrm{ab}$ & $158.40 \pm 14.09 d$ & $3.33 \pm 0.04 d$ & $4.59 \pm 1.80$ & $8.15 \pm 2.17$ \\
\hline $\mathrm{N}+\mathrm{CaO}$ & $11.15 \pm 0.21$ & $4.10 \pm 0.01 b$ & $8.81 \pm 0.24 a$ & $1.08 \pm 0.18 a b$ & $69.98 \pm 3.64 a b$ & $6.54 \pm 0.12 f$ & $6.38 \pm 3.63$ & $0.53 \pm 0.08$ \\
\hline $\mathrm{NK}+\mathrm{CaO}$ & $11.61 \pm 0.09$ & $4.46 \pm 0.08 c$ & $6.87 \pm 0.56 a$ & $2.27 \pm 0.26 b$ & $42.35 \pm 3.08 a$ & $5.27 \pm 0.31 \mathrm{e}$ & $8.44 \pm 1.99$ & $1.64 \pm 0.23$ \\
\hline $\mathrm{NP}+\mathrm{CaO}$ & $11.70 \pm 0.18$ & $4.15 \pm 0.04 b$ & $12.05 \pm 1.20 \mathrm{a}$ & $1.21 \pm 0.19 a b$ & $92.14 \pm 9.84 b$ & $8.13 \pm 0.13 g$ & $9.66 \pm 4.68$ & $1.87 \pm 0.49$ \\
\hline $\mathrm{NPK}+\mathrm{CaO}$ & $10.97 \pm 0.08$ & $4.31 \pm 0.01 c$ & $13.37 \pm 1.36 a$ & $0.63 \pm 0.12 \mathrm{ab}$ & $123.48 \pm 6.94 c$ & $6.93 \pm 0.09 f$ & $24.2 \pm 5.42$ & $4.58 \pm 0.03$ \\
\hline
\end{tabular}

a Treatment: control without fertilizers (Ctrol), and with fertilizers $\mathrm{N}, \mathrm{NK}, \mathrm{NP}, \mathrm{NPK}$, and their counterpart with $\mathrm{CaO}, \mathrm{N}+\mathrm{CaO}, \mathrm{NK}+\mathrm{CaO}, \mathrm{NP}+\mathrm{CaO}, \mathrm{NPK}+\mathrm{CaO}$.

b Mean $\pm \mathrm{SD}(\mathrm{n}=3)$. Values within the same column followed by the same letter do not differ at $P<0.05$. 


\section{a}
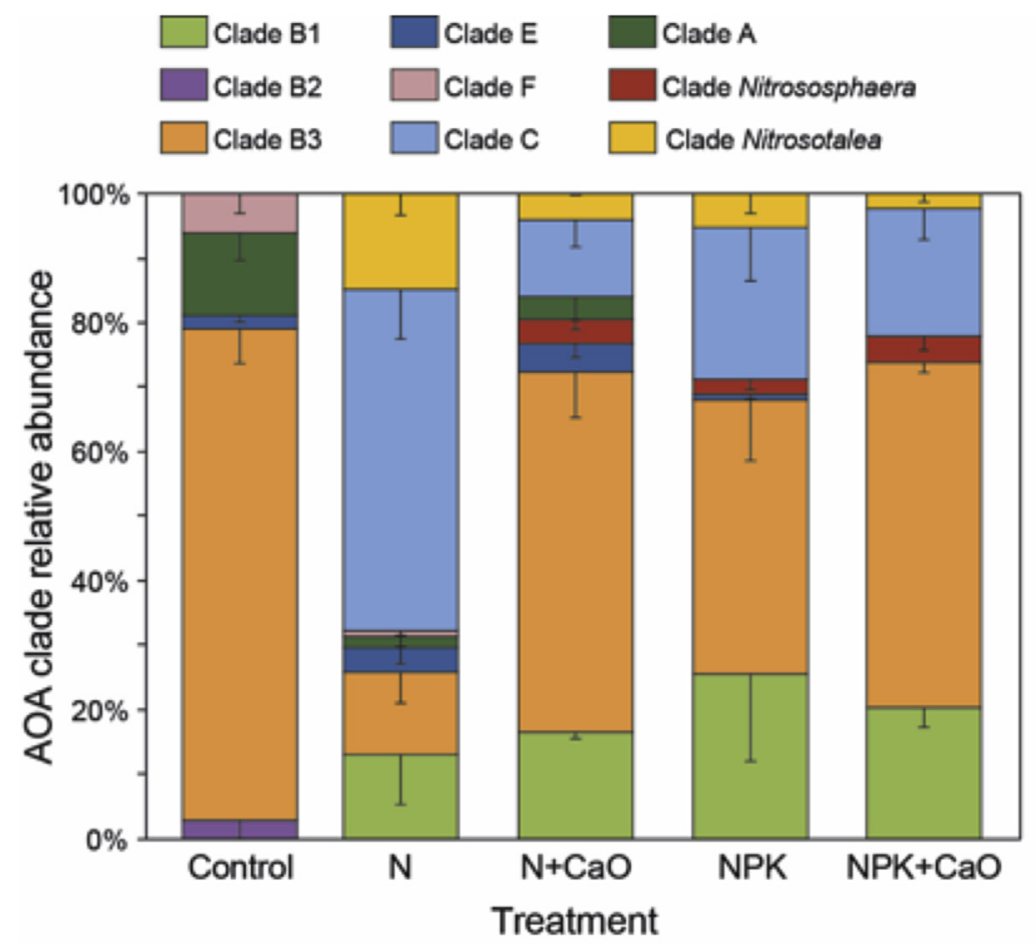

$\begin{array}{ll}\text { b } & \square \text { Nitrosospira sp. Nsp65/L115 clade (9-10) } \square \text { N. lacus clade } \\ \square \text { Nitrosospira sp. Nsp2/Nsp17 clade (3a.1) } \square \text { N. briensis clade (3b) } \\ \square \text { N. multiformis clade (3a.2) }\end{array}$

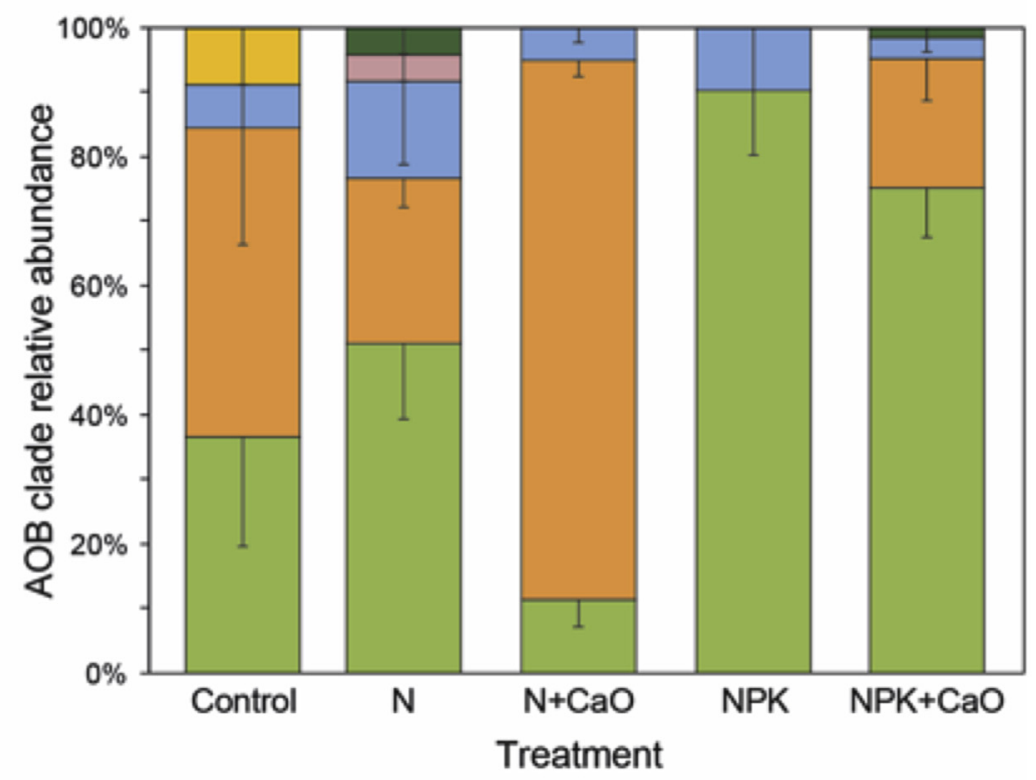

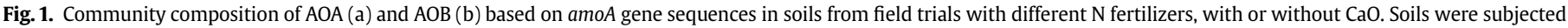

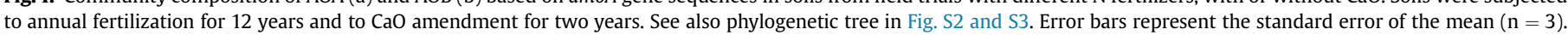

was measured in the $\mathrm{N}+2000$ treatment ( $\mathrm{pH} 4.37$ ), followed by $\mathrm{N}+1000$ and $\mathrm{N}+500$ treatments (3.82 and 3.62, respectively). The lowest $\mathrm{pH}$ value of 3.35 was measured in the $\mathrm{N}$ treatment without $\mathrm{CaO}$ addition. Nitrate concentrations generally increased throughout the incubation while ammonia concentration decreased sharply after 7 days in all treatments (Fig. 2), which indicated active nitrification. Net nitrification rates, defined as net accumulation of $\mathrm{NO}_{3}^{-}$per gram dry soil per day, were considerably higher during the first seven days of incubation, and significantly higher in the $\mathrm{N}+2000$ treatment $\left(0.34 \mu \mathrm{g} \mathrm{NO}_{3}^{-}-\mathrm{N} \mathrm{g}^{-1} \mathrm{~d}^{-1}\right)$ than in treatments with lower or no $\mathrm{CaO}$ addition $\left(0.21-0.25 \mu \mathrm{g} \mathrm{NO}_{3}^{-}-\mathrm{N} \mathrm{g}^{-1}\right.$ $\left.\mathrm{d}^{-1}\right)$. 
a

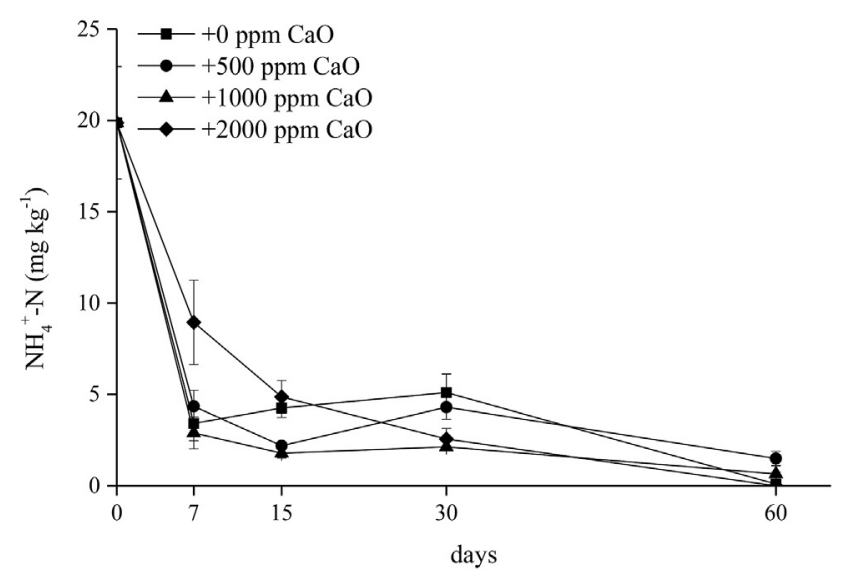

b

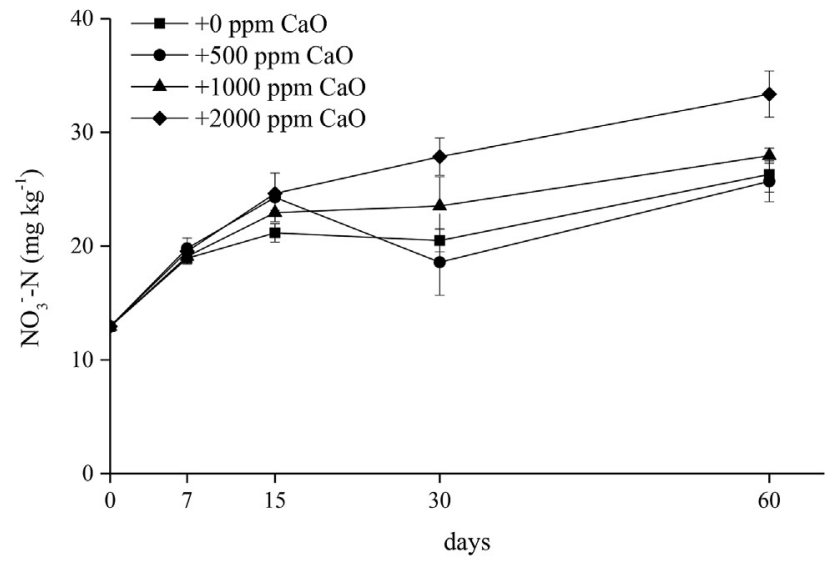

Fig. 2. Ammonium (a) and nitrate (b) concentrations during incubation of $\mathrm{N}$-fertilized soil amended with 0,500, 1000 or 2000 ppm CaO. Error bars represent the standard error of the mean $(n=3)$.

AOA abundance, inferred from archaeal amoA gene abundance, increased steadily throughout the incubation period under all treatments, although this increase was only significant in soils amended with the lowest $\mathrm{CaO}$ concentration $(\mathrm{N}+500)$ and without $\mathrm{CaO}$ addition $(\mathrm{N})(P<0.05$ at day 60$)$. AOA abundance increased significantly from $8.51 \times 10^{7}$ amoA gene copies $g^{-1}$ dry soil at day 0 to $5.40 \times 10^{8}$ and $5.86 \times 10^{8}$ amo $A$ gene copies $\mathrm{g}^{-1}$ dry soil at day 60 in the $\mathrm{N}$ and $\mathrm{N}+500$ treatments, respectively (Fig. 3a). Increases in AOA abundance were less pronounced under high $\mathrm{CaO}$ treatments $(\mathrm{N}+1000$ and $\mathrm{N}+2000)$, resulting in significantly higher AOA abundance in lower $(\mathrm{N}+500)$ or no $\mathrm{CaO}$ (N) than in high $\mathrm{CaO}$ treatments $(\mathrm{N}+1000, \mathrm{~N}+2000)$ at day 15,30 and $60(P<0.05)$ (Fig. 3a). By contrast, AOB abundance did not change significantly in the $\mathrm{N}$ and $\mathrm{N}+500$ treatments, despite an apparent small decrease, particularly in the untreated control. However, AOB abundance increased sharply and significantly over the initial seven days of incubation under the highest $\mathrm{CaO}$ amendments, from $4.08 \times 10^{6}$ to $1.65 \times 10^{7}(\mathrm{~N}+1000 ; P<0.05)$ and $1.70 \times 10^{7}(\mathrm{~N}+2000 ; P<0.05)$ amoA gene copies $\mathrm{g}^{-1}$ dry soil at day 7 , followed by a significant decrease to $5.10 \times 10^{6}(\mathrm{~N}+1000)$ and $2.59 \times 10^{6}(\mathrm{~N}+2000)$ amoA gene copies $\mathrm{g}^{-1}$ dry soil at day 60 , respectively $(P<0.05)$ (Fig. 3b).

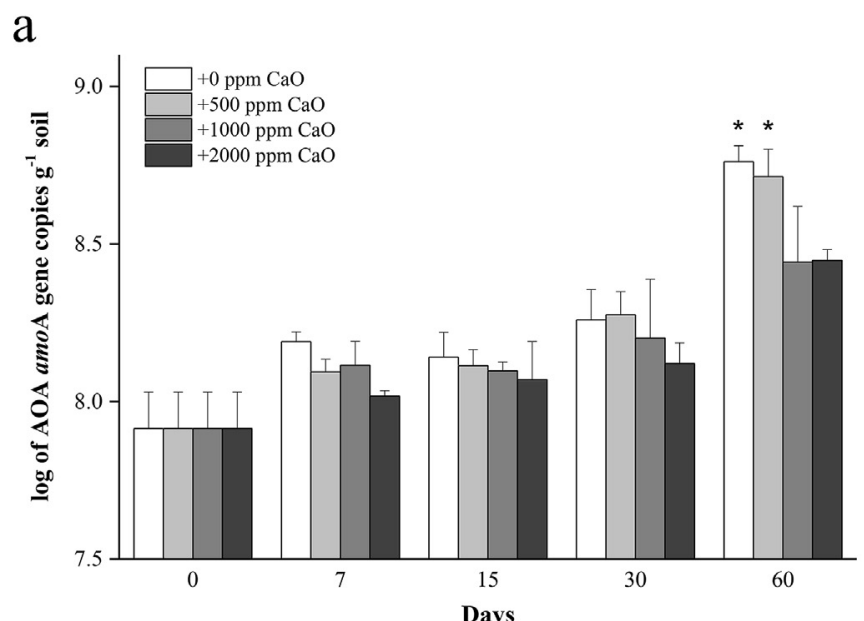

b

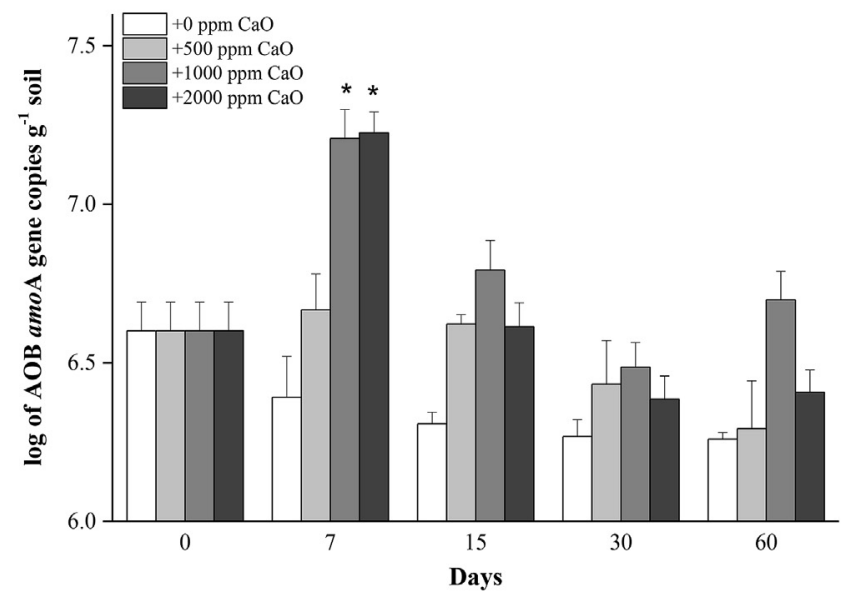

Fig. 3. $A O A$ (a) and $A O B(b)$ abundance, based on amoA gene quantification, during microcosm incubations of $\mathrm{N}$-treated soil amended with $0,500,1000$ or $2000 \mathrm{ppm} \mathrm{CaO}$ Error bars represent the standard error of the mean $(\mathrm{n}=3)$. ${ }^{*}$ means significant difference $(P<0.05)$.

\subsection{DNA-SIP incubation}

In order to assess the active ammonia oxidizer populations in response to liming, soil from field $\mathrm{N}$ and $\mathrm{N}+\mathrm{CaO}$ treatments, and from field $\mathrm{N}$ treatment soil freshly amended with $1000 \mathrm{ppm} \mathrm{CaO}$ $(\mathrm{N}+1000)$, were incubated in microcosms with addition of ${ }^{12} \mathrm{CO}_{2}$ and ${ }^{13} \mathrm{CO}_{2}$ to the headspace, followed by DNA-SIP analysis. Similar to what we observed in microcosm experiment 1 , soil $\mathrm{pH}$ in the $\mathrm{N}+1000$ treatment increased by approximately 0.5 units in relation to the $\mathrm{N}$-fertilized soil without $\mathrm{CaO}$ and remained stable over the incubation period. Likewise, $\mathrm{pH}$ in $\mathrm{N}+\mathrm{CaO}$ soils remained at about 4.1 throughout the incubation. In general, $\mathrm{NH}_{4}^{+}-\mathrm{N}$ concentrations decreased over the incubation period, concomitantly with an increase in $\mathrm{NO}_{3}^{-}-\mathrm{N}$ concentrations, indicating active nitrification in all treatments (Table 2). AOA were consistently more abundant than $A O B$ in most treatments throughout incubation, except at days 0 and 7 in the $\mathrm{N}+\mathrm{CaO}$ soil incubation. Abundance of both AOA and $\mathrm{AOB}$ remained relatively constant over time in most treatments, except in $\mathrm{N}+\mathrm{CaO}$ soil incubations, where abundance of both AOA and $A O B$ increased during the first 7 days (AOA: $P<0.05, A O B$ : $P>0.05$ ) but decreased between days 7 and 15 (AOA and AOB: $P<0.05)$, followed by another increase in abundance of AOA 


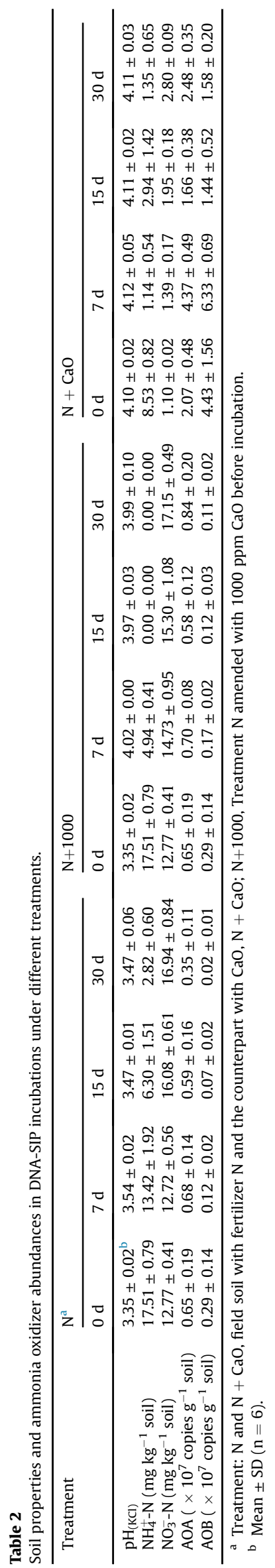

between days 15 and 30 of incubation $(P>0.05)$, but not of AOB $(P>0.05)$ (Table 2$)$.

The relative proportion of $a m o A$ genes across $\mathrm{CsCl}$ gradients was similar between $\mathrm{N}$ and $\mathrm{N}+\mathrm{CaO}$ treatments (Fig. 4). The maximum relative proportion of archaeal amo $A$ genes was initially detected in the light fractions (around a buoyant density of $1.69 \mathrm{~g} \mathrm{ml}^{-1}$ ) under ${ }^{12} \mathrm{CO}_{2}$ headspace but shifted to the heavy fractions (around a buoyant density of $1.72 \mathrm{~g} \mathrm{ml}^{-1}$ ) under ${ }^{13} \mathrm{CO}_{2}$ headspace at both days 7 and 30 (Fig. 4a), indicating that AOA grew autotrophically by assimilating $\mathrm{CO}_{2}$ during active nitrification. By contrast, no significant shift in the relative proportion of bacterial amoA genes was observed in ${ }^{12} \mathrm{CO}_{2}$ and ${ }^{13} \mathrm{CO}_{2}$ incubations throughout the $\mathrm{N}$ and $\mathrm{N}+\mathrm{CaO}$ soil incubations (Fig. 4b), thus showing no evidence of autotrophic growth by AOB. However, very different population dynamics were observed in the $\mathrm{N}+1000$ treatment: the relative proportion of bacterial amoA genes was maximal in the heavy fractions from ${ }^{13} \mathrm{CO}_{2}$ incubations after 7 days (around a buoyant density of $1.72 \mathrm{~g} \mathrm{ml}^{-1}$ ) but shifted to the light fractions after 30 days, whereas the relative proportion of archaeal $a m o A$ genes shifted to the heavy fractions only after 30 days (Fig. 4). These results indicated that $\mathrm{AOB}$ growth is stimulated by $\mathrm{CaO}$ amendment only in the short-term, although within a short period AOA take over as main active autotrophic ammonia oxidizers.

Archaeal and bacterial amoA genes were amplified and sequenced from bulk DNA extracted from samples collected at days 0,7 and 30 of all ${ }^{13} \mathrm{CO}_{2}$-SIP microcosms to assess changes in community composition throughout the incubation period. Due to unsuccessful PCR amplification, no bacterial amoA sequences were obtained from day 30 of the $\mathrm{N}$ and $\mathrm{N}+1000$ treatments. This was likely due to the much lower microbial biomass in these particular samples and general low AOB abundance. Sample storage at $4{ }^{\circ} \mathrm{C}$ for approximately four months before using for SIP incubation had considerable impact in the community composition of ammonia oxidizers in most soils, as seen in communities at the beginning of the microcosm incubations in relation to those detected soon after soil sampling (Figs. 1 and 5). The main changes in AOA communities consisted of a relative decrease in Clade $\mathrm{C}$ and increase in clade $\mathrm{B} 1$ in both $\mathrm{N}$ - and $\mathrm{N}+\mathrm{CaO}$-treated soils after storage, whereas for $\mathrm{AOB}$, only an increase in relative abundance of $N$. multiformis clade was observed in $\mathrm{N}$-treated soil. In most cases, however, both AOA and AOB communities greatly reverted towards the clade composition initially present in the samples (Figs. 1 and 5). Clade B dominated AOA communities in all microcosms, sub-clade $\mathrm{B} 1$ was the most abundant group in $\mathrm{N}$ and $\mathrm{N}+1000$ incubations, with little variability in relative abundance during incubation (Fig. 5a). In turn, the relative abundance of sub-clade B3 decreased from $20 \%$ to $1 \pm 1 \%$ during the first 7 days in the $\mathrm{N}$ treatment microcosm and was undetectable at day 30 in the $\mathrm{N}+1000$ treatment. Clade $\mathrm{C}$ was more abundant in $\mathrm{N}$ and $\mathrm{N}+1000$ microcosms than in those with $\mathrm{N}+\mathrm{CaO}$ soil, where it represented $<5 \%$ of the community from day 7 onwards (Fig. 5a). The relative abundance of clade $\mathrm{C}$ remained relatively constant throughout incubation in the $\mathrm{N}+1000$ treatment $(16 \%-20 \pm 4 \%)$ but increased progressively in the $\mathrm{N}$ treatment, from $16 \%$ at day 0 to $30 \pm 4 \%$ at day 30 (Fig. $5 \mathrm{a}$ ). Clade Nitrosotalea was detected in all microcosms at day 0 , making up $4 \%$ and $21 \%$ of the AOA communities in N/N +1000 and $\mathrm{N}+\mathrm{CaO}$ microcosms, respectively, although it was undetectable after 7 days of incubation (Fig. 5a). AOB communities were initially dominated by $N$. multiformis clade in the $\mathrm{N}$ treatment, although after 7 days AOB communities in both $\mathrm{N}$ and $\mathrm{N}+1000$ treatments were very similar to that present in the original soil, dominated by Nitrosospira sp. Nsp65/L115 and Nsp2/ Nsp17 clades (Figs. 1b and 5b). The main differences between $\mathrm{N}$ 
a
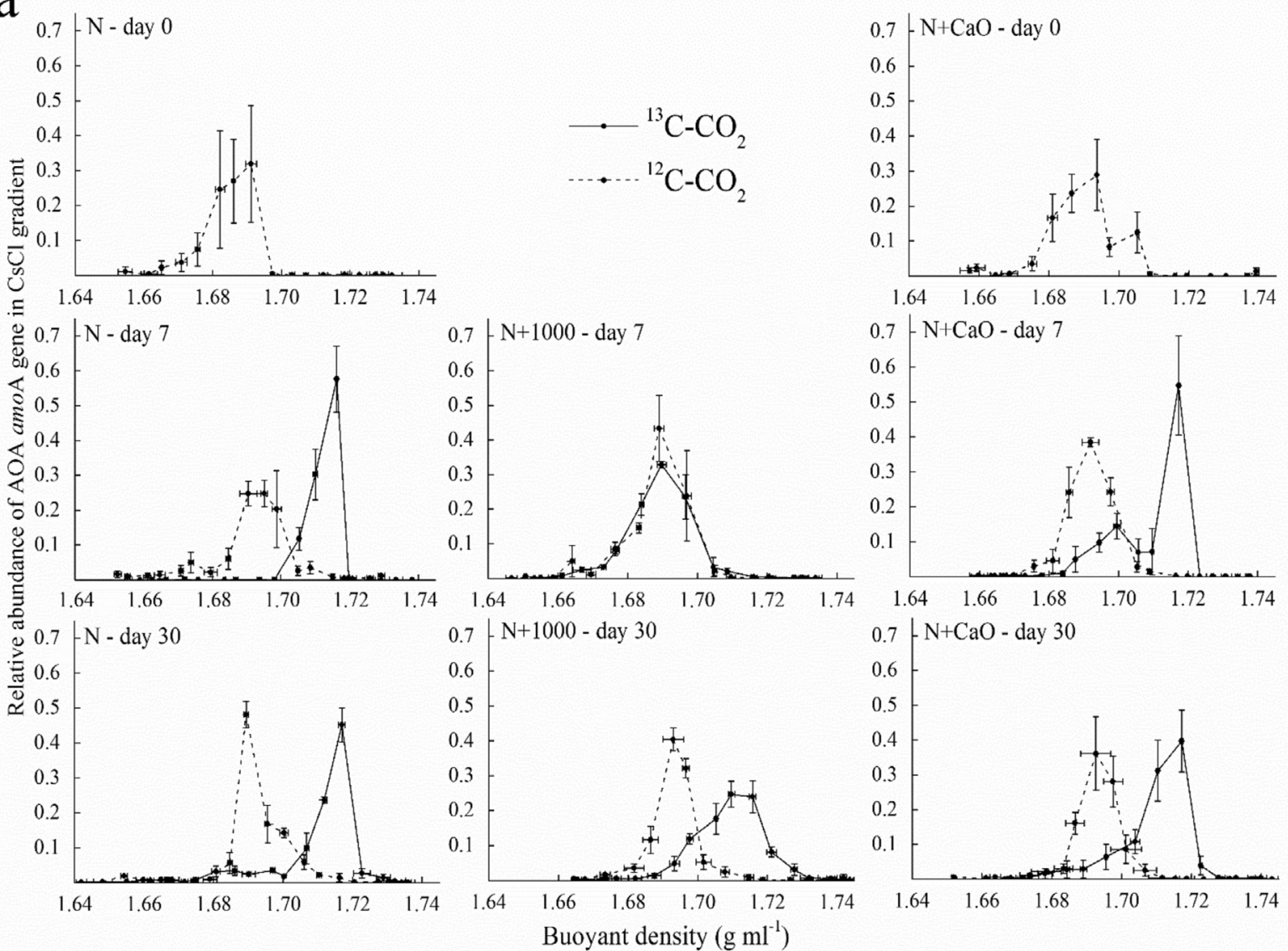

b
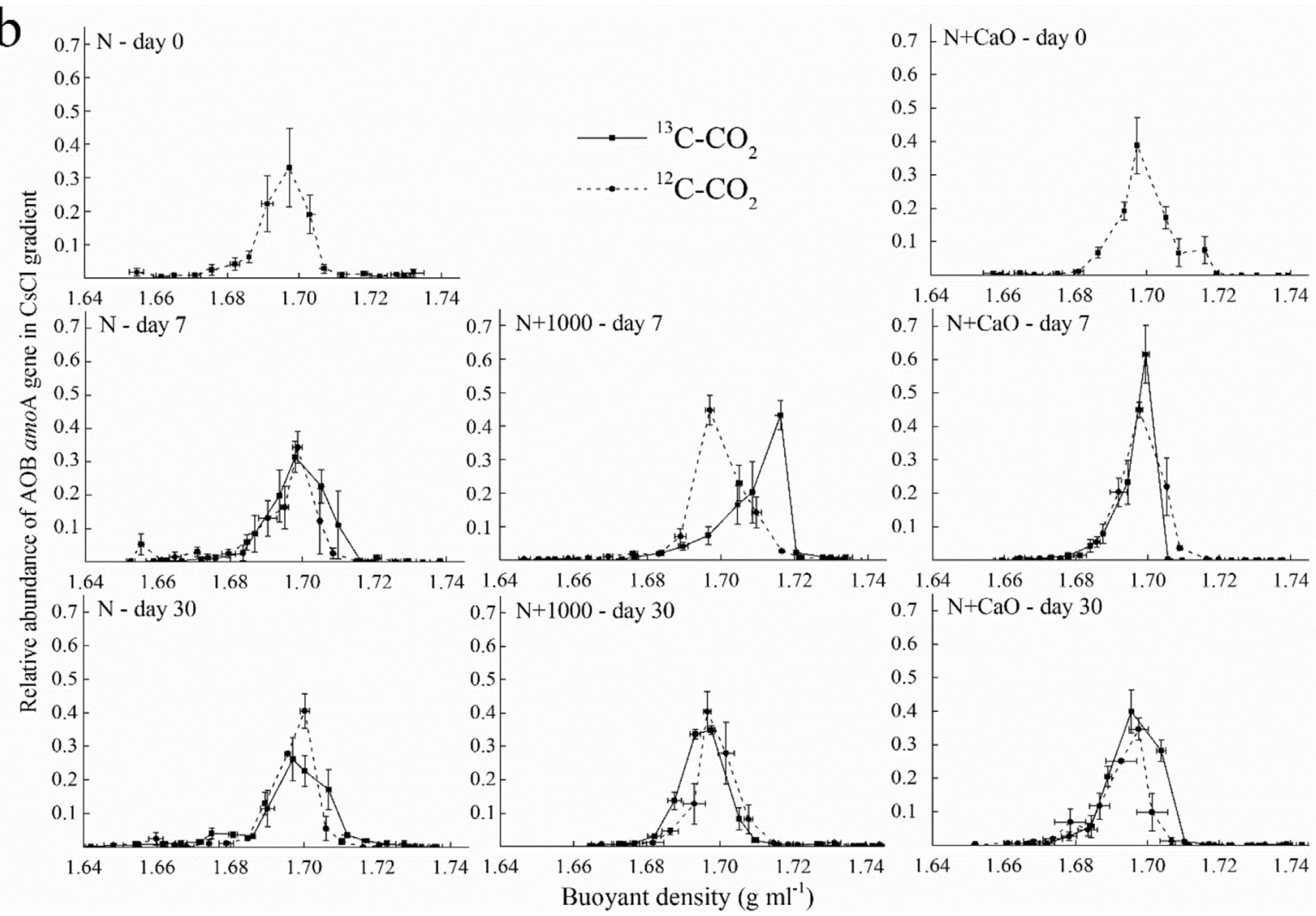

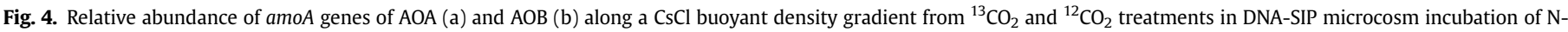

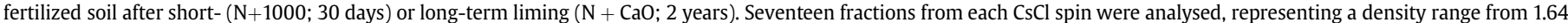

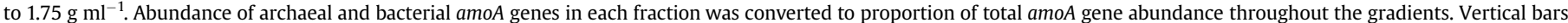

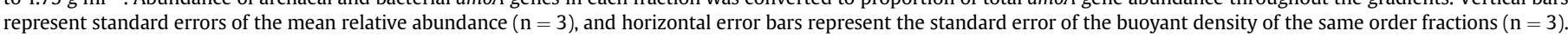


and $\mathrm{N}+1000$ microcosms at day 7 were a higher abundance of $N$. multiformis clade in the former $(26 \pm 17 \%)$ than in the later ( $5 \pm 5 \%$ ), and the detection of $N$. briensis clade only in the $N+1000$ microcosm (Fig. 5b). AOB community composition in $\mathrm{N}+\mathrm{CaO}$ microcosms was nearly identical to that in the original soil and remained relatively unchanged throughout incubation, despite a small increase in the relative abundance of Nitrosospira sp. Nsp65/ L115 from $13 \pm 4 \%$ to $26 \pm 9 \%$ (Figs. $1 \mathrm{~b}$ and $5 \mathrm{~b}$ ).

\section{Discussion}

Our results show that activity, abundance and population structure of both $A O A$ and $A O B$ are sensitive to liming in fertilized acidic soils. Both AOB abundance and PNRs increased significantly in field plots after a 2-year liming trial, whereas the opposite was observed for AOA abundance. In microcosm incubations amended with different $\mathrm{CaO}$ concentrations, the peak of $\mathrm{AOB}$ abundance occurred at day 7 in treatments with high CaO levels (1000 and 2000 ppm), whereas AOA abundance peaked at day 60 in treatments with the lowest $\mathrm{CaO}$ levels (Control and 500 ppm $\mathrm{CaO}$ ). These results suggest that liming generally favours AOB growth. Both field samples and incubation microcosm experiments showed that $\mathrm{N}$ fertilizer application markedly changed the community composition of AOA and AOB, whereas liming appeared to selectively stimulate and maintain specific AOA and AOB groups, such as clade B and Nitrosospira sp. Nsp2/Nsp17 clade (3a.1), respectively. Furthermore, ${ }^{13} \mathrm{CO}_{2}$-SIP-DNA experiments showed autotrophic growth of AOA concomitant with nitrification activity in soil from the $\mathrm{N}$ and $\mathrm{N}+\mathrm{CaO}$ field treatments throughout 30-days incubations, suggesting that AOA drive nitrification in these acidic soils regardless of long-term liming, which is consistent with previous studies in other acidic soils (Zhang et al., 2012). However, in $\mathrm{N}$-treated soils freshly amended with $\mathrm{CaO}$, only autotrophic growth of AOB was observed based on ${ }^{13} \mathrm{CO}_{2}$-SIP-DNA after seven days of incubation, but not after 30 days when ${ }^{13} \mathrm{CO}_{2}$ assimilation was only observed for AOA. This indicates that AOB activity is stimulated by $\mathrm{CaO}$ addition in acidic soils in the short-term, although within less than one month, nitrification activity was again mainly driven by AOA. Taken together, our results provide evidence for timedependent shifts between autotrophic ammonia oxidation by $\mathrm{AOB}$ and $\mathrm{AOA}$ in response to liming in acidic soils.

\subsection{Liming induced $A O B$ functioning in acidic soils}

Current evidence indicates that AOA are numerically and functionally dominant over AOB in most acidic soils, whereas the latter generally predominate in neutral to alkaline soils (Di et al., 2009; Jia and Conrad, 2009; Prosser and Nicol, 2012; Schleper, 2010; Zhang et al., 2012). Due to ionization of $\mathrm{NH}_{3}$ to $\mathrm{NH}_{4}^{+}$at low $\mathrm{pH}$, acidic soils are generally ammonia-limited (De Boer and Kowalchuk, 2001). Most cultivated AOA strains have much lower ammonia concentration tolerance $(0.89-356 \mu \mathrm{M})$ than cultured $\mathrm{AOB}$ (394-40,000 $\mu \mathrm{M})$ (He et al., 2012) and, at least some strains, have also lower half-saturation constants $\left(\mathrm{K}_{\mathrm{m}}\right)$ and higher affinity for ammonia (Martens-Habbena et al., 2009; Park et al., 2010). These physiological features have thus been proposed to confer AOA a general adaptive advantage over $A O B$ in acidic environments. Consistent with these assumptions, AOA outnumbered $A O B$ in all acidic soils studied here and were the only ammonia oxidizers with detectable activity in short-term soil incubations under native conditions, regardless of long-term continuous fertilization over 16 years and lime amendment over 2 years. However, following the 2year liming trial (1000 ppm CaO), soil pH increased significantly by 0.73-1.05 units, with concomitant increases in PNRs by 2.1-11.7fold and AOB abundance by 1.9-15.6-fold. These results demonstrate that, despite general dominance of AOA in these acidic soils, AOB populations were favoured by liming in the long-term, leading to larger populations over time. Moreover, microcosm incubations and ${ }^{13} \mathrm{CO}_{2}$-DNA-SIP experiments showed that AOB can become active and take over the dominant role in autotrophic ammonia oxidation in the short-term (i.e., one week), shortly after lime amendment. AOB typically dominate ammonia oxidizer communities in $\mathrm{N}$-rich environments, such as neutral-alkaline fertilized soils, and are more stimulated than AOA by increased ammonia availability which can be enhanced by liming in different ways (Schauss et al., 2009; Verhamme et al., 2011). For instance, higher release of soil DOM (dissolved organic matter) and $\mathrm{N}$ mineralization have been observed in response to increases in soil pH following lime application (Persson et al., 1990; Curtin et al., 1998), potentially leading to higher ammonia supply rates and concomitant faster turn-over rates, despite no changes in net $\mathrm{NH}_{4}^{+}$ accumulation, as observed here. Liming has also been observed to stimulate $\mathrm{NH}_{3}$ volatilization in acidic soils, with each increment of $0.1 \mathrm{pH}$ unit driven by liming resulting in an increase of $\mathrm{NH}_{3}$ emissions to $37.9 \mathrm{~kg} \mathrm{ha}^{-1}$ compared with no lime treatment at $34.6 \mathrm{~kg} \mathrm{ha}^{-1}$ (Mkhabela et al., 2006; Smith et al., 2009; Sommer and Ersboll, 1996). Considering $\mathrm{NH}_{3}$ as the direct substrate for AOB, higher $\mathrm{NH}_{3}$ volatilization due to liming could alleviate the substrate limitation imposed by greater ionization under acidic conditions. Liming may also increase ammonia availability in acidic soils by stimulating hydrolysis of natively-produced urea or that derived from fertilizers. For example, in pine forest soils subjected to lime amendment, $\mathrm{NH}_{4}^{+}-\mathrm{N}$ accounted for $15.5 \%-18.3 \%$ of total applied urea-N $144 \mathrm{~h}$ after fertilization, whereas it accounted for $<13 \%$ without lime amendment (Niemiera et al., 2014).

\subsection{Time-dependent effects of liming on $A O A$ and $A O B$}

Soil $\mathrm{pH}$ remained stable throughout incubation of microcosms amended with different $\mathrm{CaO}$ concentrations and net nitrification rates peaked between days 0 and 7 under all treatments, concomitant with the highest net $\mathrm{NH}_{4}^{+}$consumption rates (Fig. 2). An increase in AOB abundance was only observed in the first seven days of incubation under the highest $\mathrm{CaO}$ concentrations $(\mathrm{N}+1000$ and $\mathrm{N}+2000$ ). Moreover, incorporation of ${ }^{13} \mathrm{CO}_{2}$ into bacterial amoA genes was only observed in soils subjected to fresh $\mathrm{CaO}$ amendment $(\mathrm{N}+1000)$ and only after 7 days, but not later, indicating that stimulation of $\mathrm{AOB}$ by liming is strongly timedependent. In a previous study based on 91-day incubations of acidic soils amended with three $\mathrm{CaO}$ concentrations, the increase in respiratory quotient (RQ) with soil $\mathrm{pH}$ was strongly timedependent, being greater at day 3 than at day 21, or day 91 (Bertrand et al., 2007). In a similar study following soil incubations for 57 days, the significant time-dependent effects of liming on $\mathrm{N}$ mineralization were observed in a soil with initial $\mathrm{pH}$ of 4.7 (Fuentes et al., 2006). These studies suggest that stimulation of $\mathrm{N}$ mineralization might occur immediately after lime application (i.e., at the beginning of incubation), likely providing sufficient ammonia to trigger activity and growth of $\mathrm{AOB}$ in the short-term but not enough to maintain the populations in the long-term. Similarly, in a study conducted in an acidic coniferous forest soil, Hermansson et al. (2004) compared the dynamics of AOB community between limed and non-limed forest soils in two sites and found that the increase in $\mathrm{AOB}$ abundance induced by lime was only observed in one of the two sites at the beginning of the growing season but not at the end. Our microcosm incubation experiment amended with medium and high $\mathrm{CaO}$ concentrations showed similar trends to those in the study by Hermansson et al. (2004). However, AOB abundance in our field plots were still significantly higher in all 2year limed treatments than in their corresponding non-limed soils, 
a

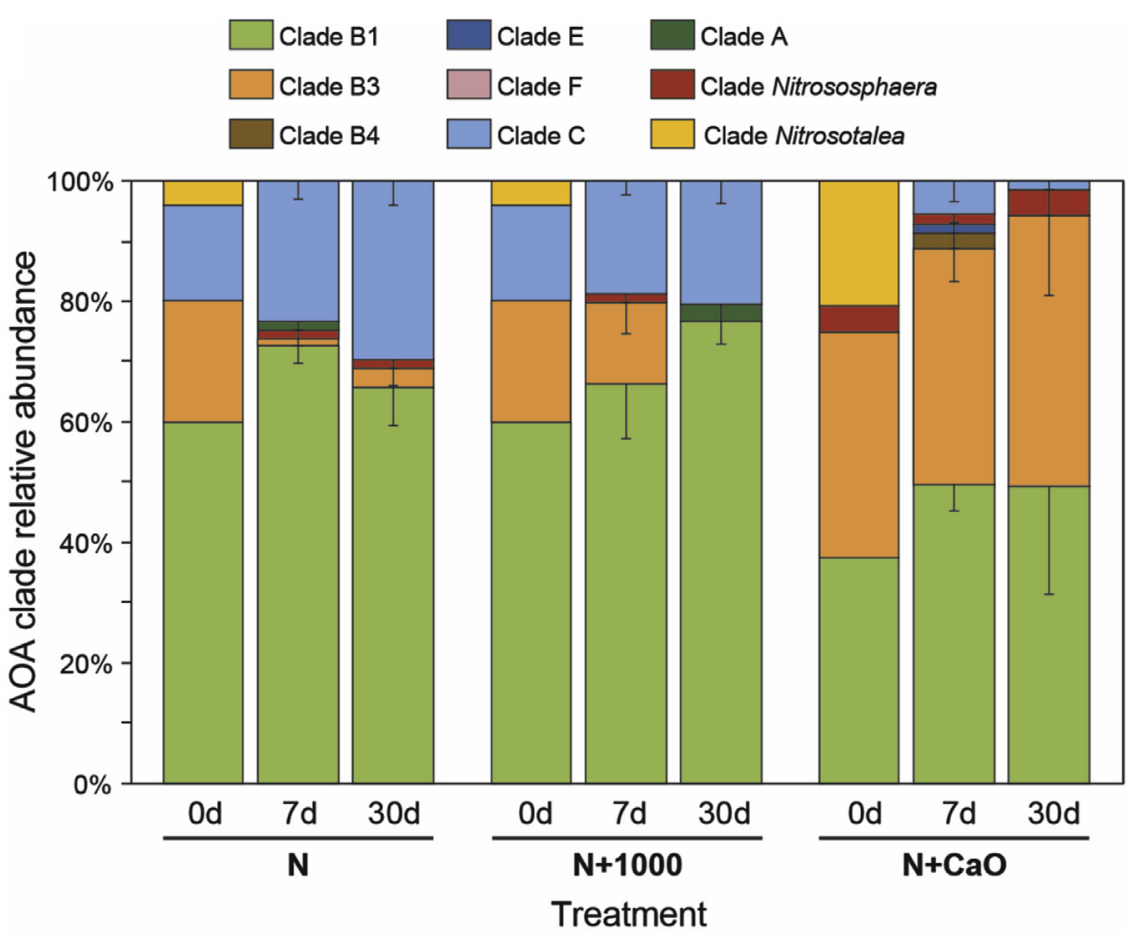

b
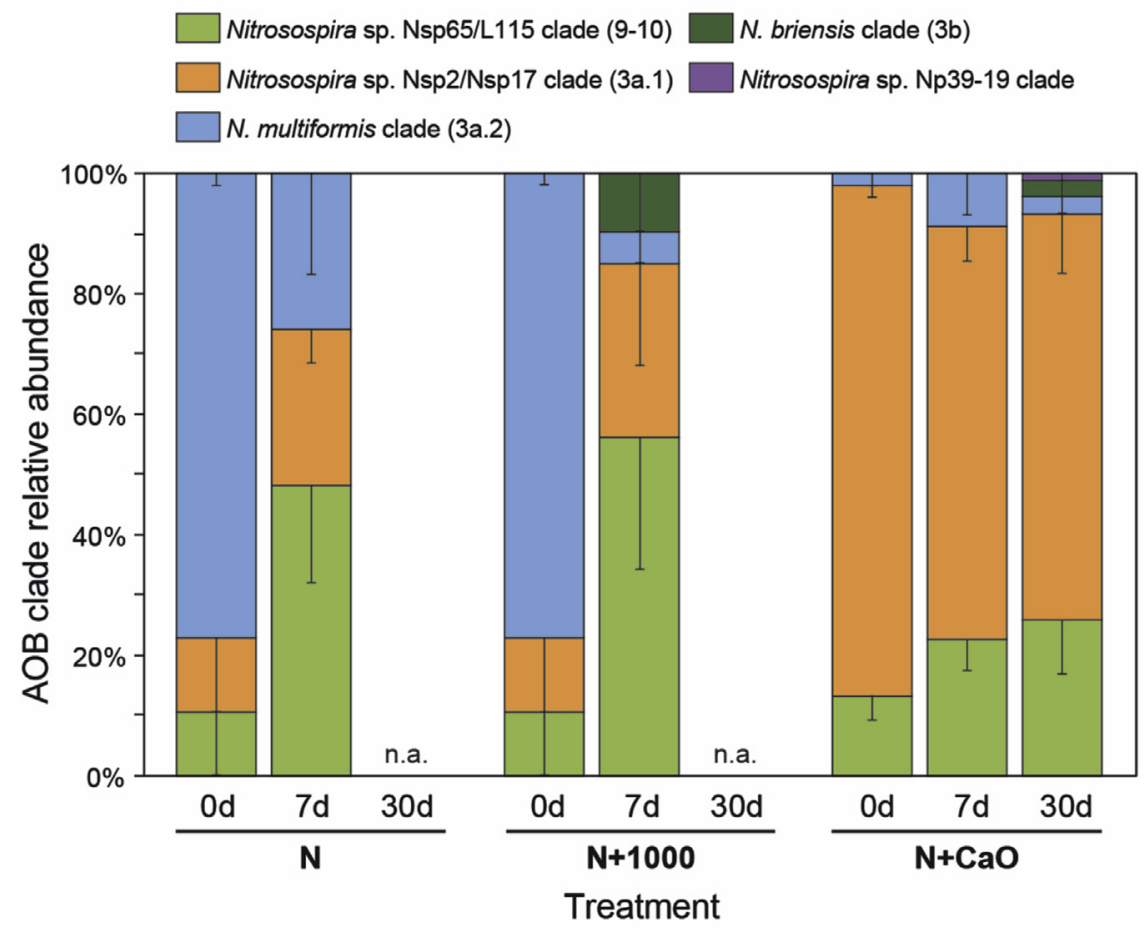

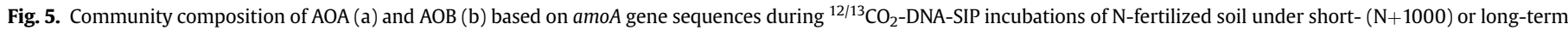
liming $(\mathrm{N}+\mathrm{CaO})$. See also phylogenetic tree in Fig. S2 and S3. Error bars represent the standard error of the mean $(\mathrm{n}=3)$. n.a., not available.

in contrast to the less pronounced stimulation of $\mathrm{AOB}$ in our microcosm incubations and in the field trial by Hermansson et al. (2004). A possible explanation for this discrepancy is the fact that the field sites in our study are located in southern China, which is characterized by a subtropical monsoon climate and consequently great annual rainfall $(1300 \mathrm{~mm})$. CaO may be partially hygroscopic and incorporated into $\mathrm{Ca}(\mathrm{OH})_{2}$ or $\mathrm{CaCO}_{3}$ aggregations after application to soils, and frequent rainfall and agricultural practices may induce them to dissolve repetitively and occasionally, providing soil conditions similar to those following fresh lime application. Therefore, such events could possibly lead to repeated bursts in AOB growth and subsequent maintenance of larger populations even after 2 years. This hypothesis is further supported by observations that intact lime pellets were detected in soil more 
than 220 days after lime application (Lollato et al., 2013).

\subsection{Profiles of $A O A$ and $A O B$ community in response to liming}

Analysis of ammonia oxidizer communities based on amoA genes showed prominent changes in relative abundance of phylogenetic clades within $\mathrm{AOA}$ and $\mathrm{AOB}$ in response to liming and fertilization, both in long and short terms. AOA communities were dominated by clade B, namely sub-clade B3, in all long-term fertilization field plots except under $\mathrm{N}$ treatment, where clade $\mathrm{C}$ predominated (Fig. 1a). Fertilization had a general selective effect on AOA communities, by comparison with unfertilized soil, as seen by the emergence of clades C, B1 and Nitrosotalea, and relative decrease of clades A, B2 and F, often to undetectable levels. In a study of distinct Arctic soils, clade B dominated ammonia oxidizer communities in an acidic and $\mathrm{NH}_{4}^{+}$-limited shrub tundra soil, where AOB were undetectable, and were likely responsible for threefold higher gross nitrification rates after ammonium addition (Alves et al., 2013). Moreover, most of AOA from clade B in that study (SO-S phylotype; Fig. S2) correspond to the sub-clade B1 defined here (Fig. S2), which were positively selected in all $\mathrm{N}$-fertilized soils in our study (Fig. 1a). Our observations thus corroborate the dominant role in acidic soils and ammonium preferences of this (sub-)clade. The short-term relative decrease of AOA sub-clade B3 in SIP microcosms after fresh lime amendment is intriguing as it was not reflected on communities in field soils subjected to liming for two years. It is possible that such short-term dynamics were not reflected on AOA communities in the long-term, or resulted from artificial conditions imposed by laboratory storage and incubation. It is also possible that different sub-clades, such as B1 and B3, have different $\mathrm{pH}$ optima, despite their general adaptation to low $\mathrm{pH}$, as previously observed across a great diversity of soil AOA (GubryRangin et al., 2011). Clade C was only detected in fertilized soils and dominated AOA communities in soils fertilized only with $\mathrm{N}$, where its relative abundance was drastically reduced after liming for two years (Fig. 1a). Similarly, the relative abundance of this clade increased in SIP microcosms with N-treated soil $(\mathrm{N})$, whereas it remained unchanged after fresh lime amendment $(\mathrm{N}+1000)$ and comprised $\leq 6 \%$ of AOA communities in incubations of $\mathrm{N}+\mathrm{CaO}-$ treated soil (Fig. 5a). Previous multivariate statistical analyses also suggested that $A O A$ from clade $C$ prefer wet organic soils with high $\mathrm{N}$ (particularly $\mathrm{NO}_{3}^{-}$) and low DOC (dissolved organic carbon) to TDN (total dissolved nitrogen) ratios, such as N-rich peatlands (Alves et al., 2013). In agreement with these observations, the soils studied here were collected in a region with subtropical monsoon climate with high rainfall and $\mathrm{N}$ treatment soils contained the highest $\mathrm{NH}_{4}^{+}$and $\mathrm{NO}_{3}^{-}$concentrations (Tables 1 and 2). Furthermore, a recent study also showed that AOA associated with this clade were enriched in soils following a 44-year $\mathrm{N}$ fertilization trial, by comparison with unfertilized soils (Zhou et al., 2015). These results indicate that clade $\mathrm{C}$ organisms are adapted to high $\mathrm{N}$ levels and appear to be inhibited by liming. Ammonia oxidation ability of AOA from clade $C$ was first shown in enrichment cultures from Arctic soils (Alves et al., 2013), which also identified this amoA gene clade (also referred to as "Nitrososphaera-sister cluster" (Pester et al., 2012) as being associated with the fosmid clone $29 \mathrm{i} 4$ that represents an AOA group often found in soils. Remarkably, the recently isolated representative of clade $\mathrm{C}, \mathrm{Ca}$. Nitrosocosmicus franklandus $\mathrm{C} 13$, has the highest $\mathrm{NH}_{4}^{+}$tolerance and growth optimum among cultivated AOA, which are within the range of those of AOB (Lehtovirta-Morley et al., 2016).

AOB communities in field soils were dominated by Nitrosospira sp. clades Nsp65/L115 and Nsp2/Nsp17, whose relative abundance was greatly affected by both fertilization and liming: Nitrosospira sp. Nsp65/L115 clade was generally favoured in the more acidic fertilized soils, whereas Nitrosospira sp. Nsp2/Nsp17 had higher relative abundance in the corresponding limed and control soils with higher $\mathrm{pH}$ (Fig. 1b and S3). These results are consistent with a meta-analysis of ammonia oxidizers in Chinese soils showing that Nitrosospira sp. Nsp2/Nsp17 clade (clade 3a.1) has been more frequently detected in neutral to alkaline soils and that Nitrosospira sp. Nsp65/L115 clade (clades 9-10) typically dominated strongly acidic soils (Shen et al., 2012). Additionally, at least one representative of Nitrosospira sp. Nsp65/L115 clade, Nitrosospira sp. strain AF, has been isolated from red acidic sandy soil ( $\mathrm{pH} 4.0$ ). In SIP microcosms with $\mathrm{N}$-treated soils, the relative abundance of Nitrosospira sp. Nsp65/L115 clade recovered to levels similar to those in the original soil, although without noticeable difference after fresh lime amendment. This suggests that, similarly to what we observed for AOA communities, such short-term population dynamics did not necessarily reflect the net effect of liming in the field in the long-term, such as after the 2-year liming trial. Unfortunately, assessment of further AOB community composition dynamics in soil incubation was hindered by the inability to amplify bacterial amoA genes from day 30 samples. Fresh lime amendment might nevertheless stimulate soil ammonia oxidizers through transiently higher $\mathrm{NH}_{3}$ availability derived from increased urea hydrolysis and DOM release and mineralization. For instance, the assimilation of ${ }^{13} \mathrm{CO}_{2}$ by AOB at day 7 after fresh lime amendment and concomitant peak in net nitrification without noticeable change in population size suggests that a flush of $\mathrm{NH}_{3}$ could have stimulated activity by well-adapted and highly efficient nitrifiers. In fact, Nitrosospira sp. AF, a representative of Nitrosospira sp. Nsp65/L115 clade, is able to grow under highly acidic conditions at extremely slow rates (138 h) but with higher ammonia oxidization activity $\left(7.1 \mathrm{fmol} \mathrm{NO}_{2}^{-}\right.$cell $^{-1}$ $\mathrm{h}^{-1}$ ) than at least some other Nitrosospira strains (e.g., strains 40KI, L115 and B6) (Jiang and Bakken, 1999).A previous study showed that AOA are also functionally heterogeneous, with different AOA clades harbouring distinct nitrification capabilities (Alves et al., 2013). Taken together, this suggests that the time-dependent selective effect of liming on populations of both AOA and AOB observed here is likely to affect gross nitrification activity and consequently also $\mathrm{N}$ losses, namely as reactive $\mathrm{N}$ species, depending on the interplay between fertilization and lime amendment regimes.

\section{Conclusion}

In conclusion, liming of acidic soils greatly affects both the abundance and community structure of ammonia oxidizers, leading to changes in dominant clades and net nitrification activity that could not be individually explained by $\mathrm{pH}$ or $\mathrm{NH}_{4}^{+}$availability. As expected, AOA generally dominated these acidic soils, although AOB also played a role in response to liming, namely in the shortterm, with AOA and AOB alternating as the main active ammonia oxidizers in a time-dependent manner. However, the possible repeated stimulation of highly adapted and efficient $A O B$ due to recurrent effects of liming likely led to the greater $A O B$ abundance and higher soil nitrification potential observed after two years of liming. Our results provide fundamental insights into nitrifier dynamics in response to liming in acidic soils and relevant knowledge for fertilization and liming strategies in agroecosystem management.

\section{Conflict of interest}

The authors declare no conflict of interest. 


\section{Acknowledgements}

This work was financially supported by the National Natural Science Foundation of China (41322007, 41171217) and Youth Innovation Promotion Association (2012031), Chinese Academy of Sciences. Ricardo J. E. Alves was funded by project P25369 of the Austrian Science Fund (FWF). We would like to thank Prof. Minggang $\mathrm{Xu}$ for access to the long-term experimental field plots, $\mathrm{Mr}$ Boren Wang and Mr Dongchu Li for assistance in soil sampling, and Dr. Hangwei Hu and Mr Tong Sun for technical support.

\section{Appendix A. Supplementary data}

Supplementary data related to this article can be found at http:// dx.doi.org/10.1016/j.soilbio.2017.05.001.

\section{References}

Abell, G.C., Robert, S.S., Frampton, D.M., Volkman, J.K., Rizwi, F., Csontos, J., Bodrossy, L., 2012. High-throughput analysis of ammonia oxidiser community composition via a novel, amoA-based functional gene array. PLoS One 7, e51542.

Álvarez, E., Viadé, A., Fernández-Marcos, M.L., 2009. Effect of liming with different sized limestone on the forms of aluminium in a Galician soil (NW Spain). Geoderma 152, 1-8.

Alves, R.J., Wanek, W., Zappe, A., Richter, A., Svenning, M.M., Schleper, C., Urich, T., 2013. Nitrification rates in Arctic soils are associated with functionally distinct populations of ammonia-oxidizing archaea. The ISME Journal 7, 1620-1631.

Andert, J., Wessén, E., Börjesson, G., Hallin, S., 2011. Temporal changes in abundance and composition of ammonia-oxidizing bacterial and archaeal communities in a drained peat soil in relation to $\mathrm{N}_{2} \mathrm{O}$ emissions. Journal of Soils and Sediments 11, 1399-1407.

Avrahami, S., Bohannan, B.J., 2007. Response of Nitrosospira sp. strain AF-like ammonia oxidizers to changes in temperature, soil moisture content, and fertilizer concentration. Applied and Environmental Microbiology 73, 1166-1173.

Barton, L., Gleeson, D.B., Maccarone, L.D., Zúñiga, L.P., Murphy, D.V., 2013. Is liming soil a strategy for mitigating nitrous oxide emissions from semi-arid soils? Soil Biology and Biochemistry 62, 28-35.

Bernhard, U., 1986. Natural and anthropogenic components of soil acidification. Journal of Plant Nutrition and Soil Science 149, 702-717.

Bertrand, I., Delfosse, O., Mary, B., 2007. Carbon and nitrogen mineralization in acidic, limed and calcareous agricultural soils: apparent and actual effects. Soil Biology and Biochemistry 39, 276-288.

Bolan, N.S., Hedley, M.J., 2005. Role of carbon, nitrogen, and sulfur cycles in soil acidification. In: Rengel, Z. (Ed.), Handbook of Soil Acidity. CRC press, New York, pp. 29-56.

Caires, E.F., Garbuio, F.J., Churka, S., Barth, G., Corrêa, J.C.L., 2008. Effects of soil acidity amelioration by surface liming on no-till corn, soybean, and wheat root growth and yield. European Journal of Agronomy 28, 57-64.

Che, J., Zhao, X.Q., Zhou, X., Jia, Z.J., Shen, R.F., 2015. High pH-enhanced soil nitrification was associated with ammonia-oxidizing bacteria rather than archaea in acidic soils. Applied Soil Ecology 85, 21-29.

Curtin, D., Campbell, C., Jalil, A., 1998. Effects of acidity on mineralization: pHdependence of organic matter mineralization in weakly acidic soils. Soil Biology and Biochemistry 30, 57-64.

De Boer, W., Kowalchuk, G., 2001. Nitrification in acid soils: micro-organisms and mechanisms. Soil Biology and Biochemistry 33, 853-866.

Di, H.J., Cameron, K.C., Shen, J.P., Winefield, C.S., O'Callaghan, M., Bowatte, S., He, J.Z., 2009. Nitrification driven by bacteria and not archaea in nitrogen-rich grassland soils. Nature Geoscience 2, 621-624.

Edgar, R.C., 2013. UPARSE: highly accurate OTU sequences from microbial amplicon reads. Nature Methods 10 (10), 996-998.

Fan, F., Yang, Q., Li, Z., Wei, D., Cui, X., Liang, Y., 2011. Impacts of organic and inorganic fertilizers on nitrification in a cold climate soil are linked to the bacterial ammonia oxidizer community. Microbial Ecology 62, 982-990.

Farmaha, B.S., 2014. Evaluating animo model for predicting nitrogen leaching in rice and wheat. Arid Land Research and Management 28, 25-35.

Fornara, D.A., Steinbeiss, S., McNamara, N.P., Gleixner, G., Oakley, S., Poulton, P.R., Macdonald, A.J., Bardgett, R.D., 2011. Increases in soil organic carbon sequestration can reduce the global warming potential of long-term liming to permanent grassland. Global Change Biology 17, 1925-1934.

Francis, C.A., Roberts, K.J., Beman, J.M., Santoro, A.E., Oakley, B.B., 2005. Ubiquity and diversity of ammonia-oxidizing archaea in water columns and sediments of the ocean. Proceedings of the National Academy of Science of the United States of America 102, 14683-14688.

Fuentes, J.P., Bezdicek, D.F., Flury, M., Albrecht, S., Smith, J.L., 2006. Microbial activity affected by lime in a long-term no-till soil. Soil and Tillage Research 88 , $123-131$.

Gleeson, D.B., Müller, C., Banerjee, S., Ma, W., Siciliano, S.D., Murphy, D.V., 2010. Response of ammonia oxidizing archaea and bacteria to changing water filled pore space. Soil Biology and Biochemistry 42, 1888-1891.

Gubry-Rangin, C., Nicol, G.W., Prosser, J.I. 2010. Archaea rather than bacteria control nitrification in two agricultural acidic soils. FEMS Microbiology Ecology 74, 566-574.

Gubry-Rangin, C., Hai, B., Quince, C., Engel, M., Thomson, B.C., James, P., Schloter, M., Griffiths, R.I., Prosser, J.I., Nicol, G.W., 2011. Niche specialization of terrestrial archaeal ammonia oxidizers. Proceedings of the National Academy of Science of the United States of America 108, 21206-21211.

Guindon, S., Dufayard, J.F., Lefort, V., Anisimova, M., Hordijk, W., Gascuel, O., 2010. New algorithms and methods to estimate maximum-likelihood phylogenies: assessing the performance of PhyML 3.0. Systematic Biology 59, 307-321.

Guo, J.H., Liu, X.J., Zhang, Y., Shen, J.L., Han, W.X., Zhang, W.F., Christie, P., Goulding, K.W., Vitousek, P.M., Zhang, F.S., 2010. Significant acidification in major Chinese croplands. Science 327, 1008-1010.

He, J.Z., Shen, J.P., Zhang, L.M., Zhu, Y.G., Zheng, Y.M., Xu, M.G., Di, H., 2007. Quantitative analyses of the abundance and composition of ammonia-oxidizing bacteria and ammonia-oxidizing archaea of a Chinese upland red soil under long-term fertilization practices. Environmental Microbiology 9, 2364-2374.

He, J.Z., Hu, H.W., Zhang, L.M., 2012. Current insights into the autotrophic thaumarchaeal ammonia oxidation in acidic soils. Soil Biology and Biochemistry 55, 146-154.

Helyar, K.R., Porter, W.M., 1989. Soil acidification, its measurement and the processes involved. In: Robson, A.D. (Ed.), Soil Acidity and Plant Growth. Academic press, Sydney, pp. 61-101.

Hermansson, A., Bäckman, J.S.K., Svensson, B.H., Lindgren, P.E., 2004. Quantification of ammonia-oxidising bacteria in limed and non-limed acidic coniferous forest soil using real-time PCR. Soil Biology and Biochemistry 36, 1935-1941.

Jia, Z., Conrad, R., 2009. Bacteria rather than Archaea dominate microbial ammonia oxidation in an agricultural soil. Environmental Microbiology 11, 1658-1671.

Jiang, Q., Bakken, L., 1999. Comparison of Nitrosospira strains isolated from terrestrial environments. FEMS Microbiology Ecology 30, 171-186.

Katoh, K., Standley, D.M., 2013. MAFFT multiple sequence alignment software version 7: improvements in performance and usability. Molecular Biology and Evolution 30, 772-780.

Kerley, S.J., 2000. The effect of soil liming on shoot development, root growth, and cluster root activity of white lupin. Biology and Fertility of Soils 32, 94-101.

Kerou, M., Alves, R.J.E., Schleper, C., 2016. Nitrososphaeria. Bergey's Manual of Systematics of Archaea and Bacteria, pp. 1-8.

Konneke, M., Bernhard, A.E., de la Torre, J.R., Walker, C.B., Waterbury, J.B., Stahl, D.A., 2005. Isolation of an autotrophic ammonia-oxidizing marine archaeon. Nature 437, 543-546.

Kurola, J., Salkinoja-Salonen, M., Aarnio, T., Hultman, J., Romantschuk, M., 2005 Activity, diversity and population size of ammonia-oxidising bacteria in oilcontaminated landfarming soil. FEMS Microbiology Letters 250, 33-38.

Lehtovirta-Morley, L.E., Ross, J., Hink, L., Weber, E.B., Gubry-Rangin, C., Thion, C. Prosser, J.I., Nicol, G.W., 2016. Isolation of 'Candidatus Nitrosocosmicus franklandus', a novel ureolytic soil archaeal ammonia oxidiser with tolerance to high ammonia concentration. FEMS Microbiology Ecology 92 fiw057.

Leininger, S., Urich, T., Schloter, M., Schwark, L., Qi, J., Nicol, G.W., Prosser, J.I., Schuster, S.C., Schleper, C., 2006. Archaea predominate among ammoniaoxidizing prokaryotes in soils. Nature 442, 806-809.

Lollato, R.P., Edwards, J.T., Zhang, H., 2013. Effect of alternative soil acidity amelioration strategies on soil pH distribution and wheat agronomic response. Soil Science Society of America Journal 77, 1831-1841.

Long, X., Chen, C., Xu, Z., Oren, R., He, J.Z., 2012. Abundance and community structure of ammonia-oxidizing bacteria and archaea in a temperate forest ecosystem under ten-years elevated $\mathrm{CO}_{2}$. Soil Biology and Biochemistry 46 $163-171$.

Lu, L., Han, W., Zhang, J., Wu, Y., Wang, B., Lin, X., Zhu, J., Cai, Z., Jia, Z., 2012 Nitrification of archaeal ammonia oxidizers in acid soils is supported by hydrolysis of urea. The ISME Journal 6, 1978-1984.

Martens-Habbena, W., Berube, P.M., Urakawa, H., de la Torre, J.R., Stahl, D.A., 2009 Ammonia oxidation kinetics determine niche separation of nitrifying archaea and bacteria. Nature 461, 976-979.

Minh, B.Q., Nguyen, M.A., von Haeseler, A., 2013. Ultrafast approximation for phylogenetic bootstrap. Molecular Biology and Evolution 30, 1188-1195.

Mkhabela, M.S., Gordon, R., Burton, D., Madani, A., Hart, W., 2006. Effect of lime, dicyandiamide and soil water content on ammonia and nitrous oxide emissions following application of liquid hog manure to a marshland soil. Plant and Soil 284, 351-361.

Nguyen, L.T., Schmidt, H.A., von Haeseler, A., Minh, B.Q., 2015. IQ-TREE: a fast and effective stochastic algorithm for estimating maximum-likelihood phylogenies. Molecular Biology and Evolution 32, 268-274.

Niemiera, A.X., Taylor, L.L., Shreckhise, J.H., 2014. Urea hydrolysis in pine tree substrate is affected by urea and lime rates. HortScience 49, 1437-1443.

Park, H.D., Wells, G.F., Bae, H., Criddle, C.S., Francis, C.A., 2006. Occurrence of ammonia-oxidizing archaea in wastewater treatment plant bioreactors. Applied and Environmental Microbiology 72, 5643-5647.

Park, B.J., Park, S.J., Yoon, D.N., Schouten, S., Sinninghe Damste, J.S., Rhee, S.K., 2010 Cultivation of autotrophic ammonia-oxidizing archaea from marine sediments in coculture with sulfur-oxidizing bacteria. Applied and Environmental Microbiology 76, 7575-7587.

Pereira, E.S.M.C., Poly, F., Guillaumaud, N., van Elsas, J.D., Salles, J.F., 2012. Fluctuations in ammonia oxidizing communities across agricultural soils are driven by soil structure and pH. Frontiers in Microbiology 3, 77. 
Persson, T., Wiren, A., Andersson, S., 1990. Effects of liming on carbon and nitrogen mineralization in coniferous forests. Water Air and Soil Pollution 54, 351-364.

Pester, M., Rattei, T., Flechl, S., Grongroft, A., Richter, A., Overmann, J., ReinholdHurek, B., Loy, A., Wagner, M., 2012. amoA-based consensus phylogeny of ammonia-oxidizing archaea and deep sequencing of amoA genes from soils of four different geographic regions. Environmental Microbiology 14, 525-539.

Prosser, J.I., 1990. Autotrophic nitrification in bacteria. Advances in Microbial Physiology 30, 125-181.

Prosser, J.I., Nicol, G.W., 2012. Archaeal and bacterial ammonia-oxidisers in soil: the quest for niche specialisation and differentiation. Trends in Microbiology 20, 523-531.

Rotthauwe, J., Witzel, K., Liesack, W., 1997. The ammonia monooxygenase structural gene $a m o A$ as a functional marker molecular fine-scale analysis of natura ammonia-oxidizing populations. Applied and Environmental Microbiology 63, 4704-4712.

Ruyters, S., Nicol, G.W., Prosser, J.I., Lievens, B., Smolders, E., 2013. Activity of the ammonia oxidising bacteria is responsible for zinc tolerance development of the ammonia oxidising community in soil: a stable isotope probing study. Soil Biology and Biochemistry 58, 244-247.

Schauss, K., Focks, A., Leininger, S., Kotzerke, A., Heuer, H., Thiele-Bruhn, S. Sharma, S., Wilke, B.M., Matthies, M., Smalla, K., Munch, J.C., Amelung, W. Kaupenjohann, M., Schloter, M., Schleper, C., 2009. Dynamics and functional relevance of ammonia-oxidizing archaea in two agricultural soils. Environmental Microbiology 11, 446-456.

Schleper, C., 2010. Ammonia oxidation: different niches for bacteria and archaea? The ISME Journal 4, 1092-1094.

Shanmugam, S., Abbott, L.K., Murphy, D.V., 2014. Clay addition to lime-amended biosolids overcomes water repellence and provides nitrogen supply in an acid sandy soil. Biology and Fertility of Soils 50, 1047-1059.

Shen, J.P., Zhang, L.M., Di, H.J., He, J.Z., 2012. A review of ammonia-oxidizing bacteria and archaea in Chinese soils. Frontiers in Microbiology 3, 296.

Smith, E., Gordon, R., Bourque, C., Campbell, A., Genermont, S., Rochette, P. Mkhabela, M., 2009. Simulated management effects on ammonia emissions from field applied manure. Journal of Environmental Management 90, $2531-2536$.

Sommer, S., Ersboll, A., 1996. Effect of air flow rate, lime amendments, and chemical soil properties on the volatilization of ammonia from fertilizers applied to sandy soils. Biology and Fertility of Soils 21, 53-60.

Soubrier, J., Steel, M., Lee, M.S., Der Sarkissian, C., Guindon, S., Ho, S.Y., Cooper, A. 2012. The influence of rate heterogeneity among sites on the time dependence of molecular rates. Molecular Biology and Evolution 29, 3345-3358.

Tourna, M., Freitag, T.E., Nicol, G.W., Prosser, J.I., 2008. Growth, activity and temperature responses of ammonia-oxidizing archaea and bacteria in soil microcosms. Environmental Microbiology 10, 1357-1364.

Treusch, A.H., Leininger, S., Kletzin, A., Schuster, S.C., Klenk, H.P., Schleper, C., 2005. Novel genes for nitrite reductase and Amo-related proteins indicate a role of uncultivated mesophilic crenarchaeota in nitrogen cycling. Environmental Microbiology 7, 1985-1995.

Uexküll, H., Mutert, E., 1995. Global extent, development and economic impact of acid soils. Plant and Soil 171, 1-15.

Venter, J.C., Remington, K., Heidelberg, J.F., Halpern, A.L., Rusch, D., Eisen, J.A., Wu, D., Paulsen, I., Nelson, K.E., Nelson, W., Fouts, D.E., Levy, S., Knap, A.H., Lomas, M.W., Nealson, K., White, O., Peterson, J., Hoffman, J., Parsons, R., BadenTillson, H., Pfannkoch, C., Rogers, Y.H., Smith, H.O., 2004. Environmental genome shotgun sequencing of the Sargasso Sea. Science 304, 66-74.

Verhamme, D.T., Prosser, J.I., Nicol, G.W., 2011. Ammonia concentration determines differential growth of ammonia-oxidising archaea and bacteria in soil microcosms. The ISME Journal 5, 1067-1071.

Wallace, A., 1994. Soil acidification from use of too much fertilizer. Communications in Soil Science and Plant Analysis 25, 87-92.

Wang, Q., Wang, S., 2011. Response of labile soil organic matter to changes in forest vegetation in subtropical regions. Applied Soil Ecology 47, 210-216.

Wrage, N., Velthof, G., van Beusichem, M., Oenema, O., 2001. Role of nitrifier denitrification in the production of nitrous oxide. Soil Biology and Biochemistry 33, 1723-1732.

Xia, W., Zhang, C., Zeng, X., Feng, Y., Weng, J., Lin, X., Zhu, J., Xiong, Z., Xu, J., Cai, Z., Jia, Z., 2011. Autotrophic growth of nitrifying community in an agricultural soil. The ISME Journal 5, 1226-1236.

Xiao, R., Chen, B., Liu, Y., Wang, C., Gu, J.D., Feng, H., Du, G., Ma, X., 2014. Higher abundance of ammonia oxidizing archaea than ammonia oxidizing bacteria and their communities in Tibetan alpine meadow soils under long-term nitrogen fertilization. Geomicrobiology Journal 31, 597-604.

Yao, H., Gao, Y., Nicol, G.W., Campbell, C.D., Prosser, J.I., Zhang, L., Han, W. Singh, B.K., 2011. Links between ammonia oxidizer community structure, abundance, and nitrification potential in acidic soils. Applied and Environmental Microbiology 77, 4618-4625.

Ying, J.Y., Zhang, L.M., He, J.Z., 2010. Putative ammonia-oxidizing bacteria and archaea in an acidic red soil with different land utilization patterns. Environmental Microbiology Reports 2, 304-312.

Zaniewicz-Bajkowska, A, Rosa, R., Franczuk, J., Kosterna, E, 2007. Direct and secondary effect of liming and organic fertilization on cadmium content in soil and in vegetables. Plant Soil and Environment 53, 473-481.

Zhang, L.M., Wang, M., Prosser, J.I., Zheng, Y.M., He, J.Z., 2009. Altitude ammoniaoxidizing bacteria and archaea in soils of Mount Everest. FEMS Microbiology Ecology 70, 52-61.

Zhang, L.M., Hu, H.W., Shen, J.P., He, J.Z., 2012. Ammonia-oxidizing archaea have more important role than ammonia-oxidizing bacteria in ammonia oxidation of strongly acidic soils. The ISME Journal 6, 1032-1045.

Zhou, X., Fornara, D., Wasson, E.A., Wang, D., Ren, G., Christie, P., Jia, Z., 2015. Effects of 44 years of chronic nitrogen fertilization on the soil nitrifying community of permanent grassland. Soil Biology and Biochemistry 91, 76-83. 